Helgoländer wiss. Meeresunters. 31, 1-33 (1978)

\title{
Interaction between genetic, external and parasitic factors in sex determination of the crustacean amphipod Gammarus duebeni
}

\author{
H.-P. BulNHEIM \\ Biologische Anstalt Helgoland (Zentrale); \\ Palmaille 9, D-2000 Hamburg 50, Federal Republic of Germany
}

\begin{abstract}
Sex determination in Gammarus duebeni duebeni was analyzed by breeding experiments conducted with individuals obtained from various populations. Sex ratio of progeny depends on genetic factors and photoperiod. Generally, a preponderance of males was noted when offspring were raised under long-day photoperiods, whereas females prevailed under short-day photoperiods (Bulnheim, 1967, 1969). Based on these previous studies the critical daylength, the transition point at which the photoperiodic response switches, was estimated in specimens from a population of the Elbe estuary as ranging between 13 and 14 hours of light per day at $15^{\circ} \mathrm{C}$. The susceptibility to photoperiod is assumed to depend on the balance between a system of male and female determining genetic factors that act on a polygenic basis. From various coastal brackish-water populations thelygenic (all-female) strains could be selected. This maternally inherited sex-ratio condition is caused by the transovarially transferred microsporidians Octosporea effeminans and Thelobania berediteria which, independently of each other, exert a feminizing influence on the host's offspring. Either perfectly or imperfectly thelygenic females may occur. The latter produce eggs that are not all infected; hence their progeny are bisexual. As a consequence of the sex-determining influence of the microsporidians males are generally not parasitized. However, some males associated with O. effeminans were found in a strain derived from a population at Bornholm (Baltic Sea). Also, males infested with one or both of the two parasite species occur in some populations of $G$. $d$. celticus, indicating that in these sex determination is not governed by the microsporidians concerned. The feminizing influence of the parasites may be affected by environmental factors. An increase of the ambient salinity level to 25-30\% results in a disappearance of $O$. effeminans in the eggs released by infected $G$. $d$. duebeni females. Thus, the normally acting switch mechanism of sex determination is re-established. In addition, long exposures to low temperatures $\left(\leqq 4^{\circ} \mathrm{C}\right.$ ) may have an adverse effect on the vegetative stages of both microsporidians. Owing to this, infected females may produce eggs which are nor all parasitized. Consequently, mixed progeny may arise. Studies on the incidence rates of the two microsporidians comprising 18 populations indicate that the parasites are widespread in their geographical range. Most populations studied in the Baltic Sea area and brackish-water habitats of the German North Sea coast are associated with either one or both of the two microsporidian parasites. Observations on the sex ratio of a population from the Elbe estuary, performed over several years, revealed considerable seasonal fluctuations. The percentages of infected females, however, remained at a fairly constant level during the study period. The results obtained are discussed with reference to the mechanisms of sex determination and differentiation as revealed in other amphipod species, in particular to the interaction of genetic and non-genetic factors and the occurrence of monogeny phenomena.
\end{abstract}




\section{INTRODUCTION}

Deviations from the $1: 1$ ratio of males to females are widespread in crustaceans. Variously skewed sex ratios have been shown to occur particularly in populations of several amphipod and isopod species. In some cases, the bias of the sex ratios observed could be attributed to the occurrence of monogeny, the production of unisexual offspring by certain pairs. Monogeny as revealed by breeding experiments is expressed either as thelygeny (all-femaleness) or arrhenogeny (all-maleness); it is opposed to amphogeny, the production of mixed progeny.

Investigations on the underlying mechanisms of sex determination have provided various and occasionally diverging results on the importance of the factors which control sex ratio. Above all, the phenomena of monogeny have received a considerable amount of attention and hence they have been subject of diverse interpretations (cf. Dalens, 1971; Legrand \& Legrand-Hamelin, 1975).

With reference to amphipods these investigations concentrated upon representatives of the genera Gammarus and Orchestia. Among them the brackish-water crustacean Gammarus duebeni duebeni has been studied in detail as to the genetic and nongenetic factors affecting determination and inheritance of sex.

Work by Traut (1962) revealed the occurrence of all-female broods in certain strains of this amphipod species and the inheritance of the monogenic condition through the maternal line. Further studies carried out in order to detect the cytoplasmic determinants, which Traut suggested to be involved, elucidated the presence of microsporidian parasites acting as causative agents of thelygeny: Associated with the ovaries of thelygenic females, they are transferred through the eggs from one generation to the next and affect sex ratio of the progeny by their feminizing influence (Bulnheim, 1967a, 1969, 1971; Bulnheim \& Vávra, 1968).

Descendants of female parents free of microsporidians do not exhibit balanced sex ratios either. In such amphogenic strains evidence could be provided for a modifying influence of photoperiod on sex determination (Bulnheim, 1967b, 1969).

This paper complements several results previously obtained on the sex-deciding mechanisms operating in $G$. d. duebeni. It reports on further studies regarding the influence of different photoperiods on sex ratio. In addition, the effects of external factors such as salinity and temperature on sex determination of individuals infested by microsporidians are described. Finally, results are presented derived from examinations of various $G$. d. duebeni and $G$. d. celticus populations with reference to the presence and incidence rates of microsporidian infections. These findings are complemented by some observations made on sex ratios occurring in the field.

\section{MATERIAL AND METHODS}

The majority of data was gained by experiments conducted with specimens of Gammarus duebeni duebeni Liljeborg obtained from the estuary of the River Elbe. The test animals were collected in ditches of the dike area near Müggendorf (FRG). Experiments were also performed with individuals obtained from some other localities 
(listed in Table 5), in particular from the brackish-water lake "Kleiner Kiel" at Kiel (FRG), Baltic Sea Fjord of Schlei (FRG), rock pools of the island of Bornholm (Denmark) and Isle of Man (U.K.). In addition, some fresh-water populations of Gammarus duebeni celticus Stock \& Pinkster* were studied; specimens of this subspecies were collected near Brasparts (Finistère, France) and on the Isle of Man (Port Erin, Poyllvaaish).

Several strains derived from pair cultures were reared in the laboratory and studied over several generations. In most experiments the gammarids were bred at $15^{\circ} \mathrm{C}$ and $10 \% \mathrm{~S}$. They were fed fresh or freeze-dried algae (Enteromorpha sp.), pieces of potatoes, Enchytraeus albidus, occasionally mantles and gonads of Mytilus edulis and the commercially available fish food "TetraMin". The offspring of each pair were counted after hatching and transferred to aerated aquaria (ca. 101 water volume). They were sexed at a body length of $8-10 \mathrm{~mm}$ after having been anaesthetized by a $0.1 \%$ solution of MS 222 (Sandoz).

In some experimental series light-dark cycles of various lengths, regulated by clockcontrolled switches, were tested. If not otherwise indicated, the intensity of the light, generated by fluorescent tubes ("Warmton de Luxe"), ranged between 50 and 100 lux as measured at the water surface of the aquaria. There was no simulation of twilight between the daylight portion (photophase) and dark portion (scotophase) of the natural $24 \mathrm{~h}$ photoperiod. For statistical analysis of the data obtained the Chi-square test was employed.

Details on further experimental procedures are given in the following chapters.

\section{GENETIC AND PHOTOPERIODIC INFLUENCES ON SEX DETERMINATION}

Traut (1962) concluded from investigations based on a series of crossbreeding experiments that a polyfactorial system of sex determination is acting in Gammarus duebeni. This mechanism implies a control of sex by independent multiple sex genes which, in the absence of sex chromosomes, are scattered over the whole chromosome complement. In addition to predeterminative influences, extrinsic factors, although not recognized by Traut, have been assumed to play a modifying role in sex determination of some genetically labile amphogenic strains.

One of the problems posed in the experiments reported here was to find out which environmental variables may control processes during oogenesis, embryogenesis or postembryonic development and thus exert an influence on sex ratio. The importance of focusing upon the early ontogeny derived from studies on the gonadal development which indicated that the young are sexually undifferentiated at hatching. They remain in this stage until organogenesis proceeds (between the fourth and fifth moult) either in the feminine or in the masculine direction, which is expressed by the appearance of small oocytes or spermatocytes in the gonads.

* The two subspecies of Gammarus duebeni have been erected by Stock \& Pinkster (1970) primarily on the basis of morphological differences regarding the merus of the fifth walking leg. 
The experiments carried out revealed photoperiod as an environmental factor to have some influence on sex expression (Bulnheim, 1967b, 1969). This could be demonstrated by subjecting equal halves of broods to different light-dark cycles and comparing sex ratios at the onset of external sex differentiation. In general, under constant

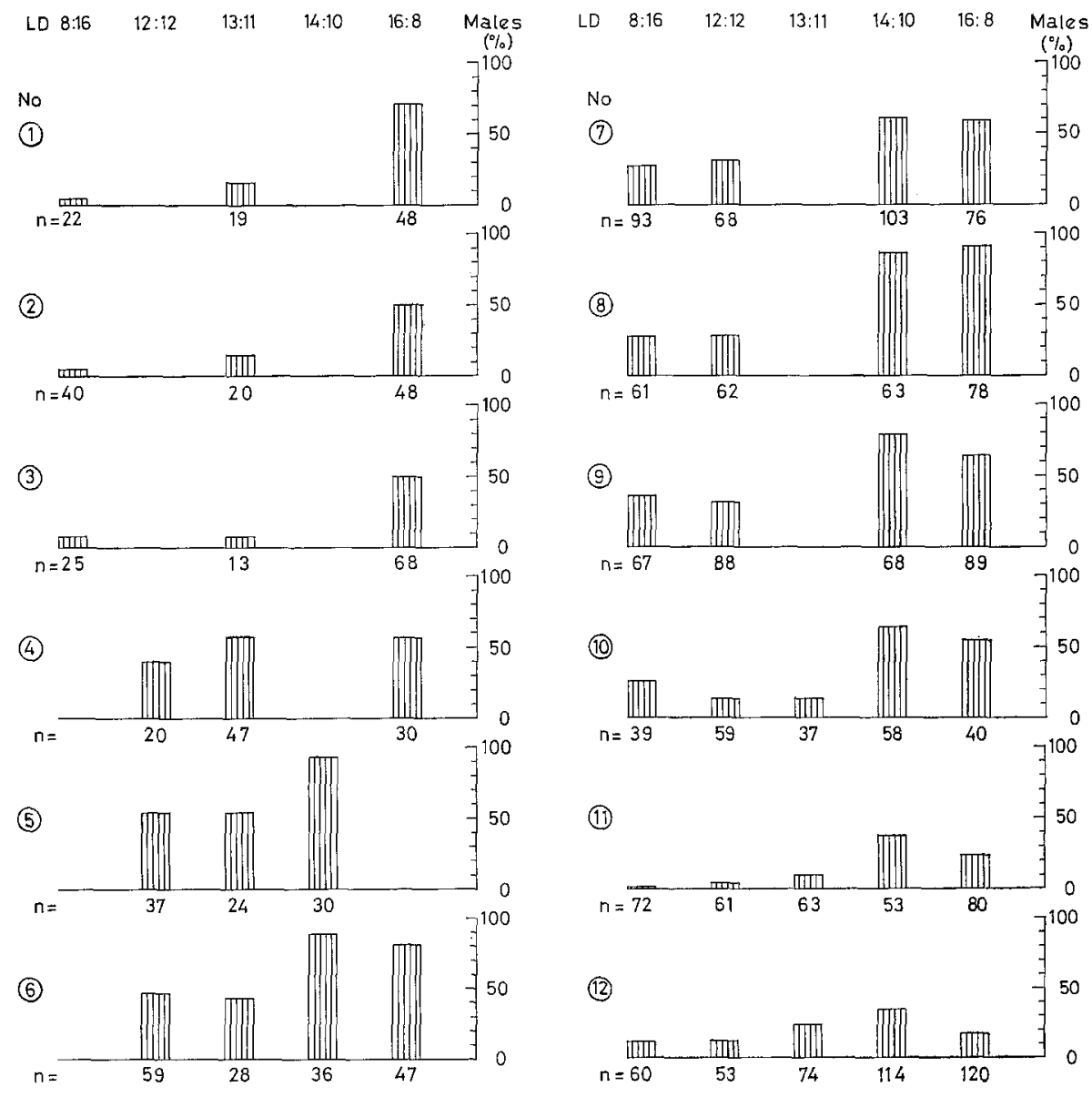

Fig. 1: Influence of different light-dark cycles (at $15^{\circ} \mathrm{C}$ and $10 \% \mathrm{~S}$ ) on sex ratio of progeny obtained from various Gammarus duebeni duebeni pairs (non-infected strain derived from the Elbe estuary population). Sex ratios expressed as percentages of males; $n=$ number of individuals sexed

temperature conditions, short-day photoperiods (LD $8: 16$ ) induce an increase in qQ, whereas $\hat{o} \hat{o}$ prevail in long-day photoperiods (LD 16:8). A photosensitive phenocritical period of sex differentiation has been recognized to occur during early ontogeny; it is delimited by the second and fourth moult. Derived from this finding various studies were made to test the influence of different photoperiodic regimes, 
ranging from continuous darkness over various lengths of the scotophase and photophase to continuous illumination. They provided evidence that exposures of young produced by a given pair to light-dark cycles of LD $8: 16,12: 12$ as well as continuous darkness result in almost equal sex ratios. Generally, the percentages of males are much lower compared to those of progeny having been exposed to LD $16: 8$ as well as to continuous light. By the application of different photoperiods the relative importance of the light versus dark phase for the shift of sex ratio could be assessed: Since the results produced under continuous darkness did not differ significantly from those observed under short-day or normal-day conditions, the length of photophase is regarded to be of primary importance.

The sex ratios observed following an exposure of the broods to LD $12: 12$ and $16: 8$ imply that the critical daylength lies between these two diel light-dark cycles. The critical daylength designates a certain light-dark cycle, that represents a transition point at which the photoperiodic response switches. Further experiments including sequences of increasing photophases were conducted in order to define more precisely the critical photoperiod in the G. $d$. duebeni population of the Elbe estuary. As demonstrated by Figure 1, the sex ratios obtained from progenies of various parents clearly show that the photophase duration in terms of the critical daylength, the point in the photoperiodic response at which the proportions of the two sexes change, may be estimated as between 13 and 14 hours of light per day at $15^{\circ} \mathrm{C}$. Although some variability in the photoperiodic responses becomes evident, the sex ratios of the offspring examined are significantly different between these two photoperiods except for those of the descendants derived from pair No 12 ( $\mathrm{P}>0.05)$.

A comparison of the sex ratios (expressed as percentages of males) from various broods that had experienced the same photoperiodic regime, but derived from different progenitors reveals some variability. As reflected by Figure 1, they are generally under the $50 \%$ level following exposures to LD $8: 16,12: 12$ and $13: 11$. On the other hand, at long-day photoperiods the percentages of $\hat{\partial} \hat{\partial}$ are mostly above the $50 \%$ level. If they are not, there is only a slight difference compared to the proportions of sex observed in photoperiods with longer scotophases. The shift of sex ratio induced by different light-dark cycles is considerable in the offspring of most progenitors. Depending on the photoperiod which the broods experience, it may even range from all-femaleness up to all-maleness; occasionally, sex ratios may be maintained at an almost constant level irrespective of the photoperiodic regimes used. In such cases a balanced sex ratio or overall high percentages of males or females may be attained. The latter is exemplified by the sex ratios of the descendants produced by pair No 4 (Fig. 1) which are not significantly different $(P>0.05)$.

It is worthy of note that cases of no or only minor photoperiodic responses have rarely been observed in offspring of progenitors obtained from the population of the Elbe estuary. Among the broods of ca. 60 pairs whose photoperiodic responses were examined after having subjected equal halves of their offspring to short and long daylengths only four provided non-significant results.

The considerable variability of sex ratio of progeny that emerged from different progenitors and the differences in the shift of the proportions of the two sexes caused by short-day and long-day photoperiods are interpreted as a result of genetic influ- 
ences. According to the theory of polygenic sex determination advanced by Kosswig (1964) an almost equally balanced system of male and female "realizators" may act together and, as a consequence of such equilibria, environmental factors are allowed to exert some influence on sex expression. The genetic system in such cases of sex determination is supposed to depend on a number of pairs of alleles or even multiple alleles localized in several chromosomes or on the whole genome. As a result of their interactions polymeric effects may play an important role in the sex-deciding process. The high degree of its relativity is reflected by the different sexual strengths which males and females may exhibit. They are indicated by diverging numbers of males and females produced in broods that arise from different crosses. To some degree, such differences could be demonstrated to occur following crosses of certain $ㅇ ㅜ$ with several males: The offspring not only revealed different percentages of males but also the shift of sex ratios induced by different daylengths varied considerably (Bulnheim, 1969).

Polygenic sex determination acting on a polymeric basis generally does not permit a prediction of sex ratio of the progeny except for the possibility of selecting some strains rich in males and others rich in females. Such selection experiments, however, have not yet been successful in G.d.duebeni.

Concluding from the above reported assumption, the difference between the sex ratios obtained under short-day and long-day photoperiods corresponds to the number of labile genotypes of the descendants which are, as a consequence of the nearly complete balanced system of male and female sex genes $(M \approx F)$, susceptible to environmental influences. Except for photoperiod, proof of an interaction of other external factors with genetic factors in sex determination of $G$. $d$. duebeni could not be furnished.

The experiments reported here for testing the role of the factor photoperiod have been conducted at light intensities of 50-100 lux. It is of physiological as well as of ecological importance to gain some knowledge on the amounts of energy required to elicit a response mediated by the receptor and effector systems involved. Therefore,

Table 1

Shitt in sex ratio of the broods produced (A, B) by three Gammarus duebeni duebeni pairs (non-infected strain derived from the Elbe-estuary population) following exposure of equal halves to short-day photoperiod (LD 8:16) and long-day photoperiod (LD 16:8). Comparison of the responses to different quantities of light

\begin{tabular}{|c|c|c|c|c|c|c|}
\hline \multirow{2}{*}{$\begin{array}{l}\text { No of } \\
\text { pairs } \\
\text { and } \\
\text { broods }\end{array}$} & \multirow[b]{2}{*}{ Photoperiod } & \multicolumn{2}{|c|}{$\sim 1-3 \operatorname{lux}$} & \multicolumn{2}{|c|}{$\sim 70-100 \mathrm{lux}$} & \multirow[b]{2}{*}{$P$} \\
\hline & & 우 : $\hat{\sigma}$ & $\begin{array}{c}\text { Mor- } \\
\text { tality } \\
(0 / 0)\end{array}$ & $q: \hat{~}$ & $\begin{array}{c}\text { Mor- } \\
\text { tality } \\
(0 / 0)\end{array}$ & \\
\hline $81 \mathrm{~A}$ & LD $8: 16$ & $32: 11$ & 4 & $21: 7$ & 7 & $>0.9$ \\
\hline B & LD $16: 8$ & $7: 38$ & 2 & $6: 22$ & 7 & $<0.5$ \\
\hline $83 \mathrm{~A}$ & LD $8: 16$ & $18: 1$ & 54 & $22: 3$ & 11 & $>0.3$ \\
\hline $\mathrm{B}$ & LD $16: 8$ & $27: 11$ & 7 & $12: 13$ & 7 & $>0.05$ \\
\hline $86 \mathrm{~A}$ & LD $8: 16$ & $52: 6$ & 13 & $26: 4$ & 12 & $>0.5$ \\
\hline B & LD $16: 8$ & $12: 39$ & 24 & $5: 25$ & 12 & $>0.3$ \\
\hline
\end{tabular}


comparative studies were made at two light intensities ( 70-100 lux and $\sim 1-3$ lux $)$ and two photoperiodic regimes.

The experimental procedure applied was similar to that outlined above: equal halves of single broods were exposed to the relatively high light intensity (as a control) and to the low quantity of light presented under short-day as well as under long-day conditions. Table 1 shows that both experimental series were responsive at the same levels in terms of the sex ratios obtained. Thus, the light-intensity response threshold must be somewhat lower than 1 lux. Although $G$. d. duebeni reveals negative phototactic reactions, it may be concluded that the rather low energy levels expected to occur in its natural habitat, in particular between and under stones and other substratum, may also become effective.

In summary, this experiment clearly demonstrates that duration and not quantity of light is responsible for the shift of sex ratio observed. Studies on the effective wavelengths, however, have not yet been accomplished.

\section{FEMINIZING INFLUENCE BY MICROSPORIDIAN INFECTIONS}

As mentioned in the introductory chapter, the occurrence of thelygenic straits in Gammarus duebeni duebeni could be ascribed to infestations by certain microsporidians. These intracellular protozoan parasites are transferred transovarially from one generation to the next and exert a feminizing influence upon their host during the process of sex differentiation. Frequently, all young are infected and thus the broods produced consist chiefly or exclusively of females. The few males which occasionally arise in such thelygenic strains derived from a population of the Elbe estuary could be shown to be not parasitized. Intersexes which, in fairly low numbers, may also emerge from infected females, are generally associated with the microsporidians. Experimental proof of their feminizing influence on the offspring of their host could be obtained by artificial contamination of non-infected females: In contrast to controls, they gave birth to offspring that were composed almost exclusively of females (Bulnheim, 1967a). The microsporidian responsible for this sex-ratio condition was recognized as Octosporea effeminans (Bulnheim \& Vávra, 1968).

In the course of these investigations a second microsporidian was detected as parasitic in several G. $d$. duebeni females. This form, Thelobania berediteria, is also transferred via the eggs and has a feminizing influence on the offspring as well (Bulnheim, 1969, 1971). These findings revealed that a hereditary parasitism accounts for the thelygeny observed in $G . d$. duebeni; the transovarial transfer of the two species provides the explanation for the maintenance and perpetuation of this sex-ratio condition through the maternal line. Except for affecting determination and inheritance of sex, neither microsporidian exerts pathogenic effects upon its host. This indicates rather well-balanced host-parasite relationships.

Major features for the recognition of the two microsporidian species under consideration are the various stages of their life cycle composed of the vegetative phase (schizogony, merogony) and the sporulation as well as the sites of infection (cf. Bulnheim \& Vávra, 1968; Bulnheim, 1971, 1975b). 
Common patterns in the development of both species refer to the multiplication of the vegetative stages in the oocytes. The latter are arranged in 3 layers of different size classes in the ovary (Fig. 2). The layer located at the periphery of the gonad comprises the largest oocytes; they exhibit a significant growth, before they are released. Generally, the meronts only invade the oocytes of the peripheral layer in which they undergo progressive multiplications in the ooplasma until vitellogenesis takes place. A second multiplicative phase is initiated after fertilization of the ova and continues during cleavage. These processes, briefly outlined here, are of some importance for an understanding of the role of environmental factors on the multiplication of the parasites as will be described below.

Rearing experiments have been conducted with infected individuals obtained from various populations. Some results regarding sex ratios of progeny emerged from parasitized specimens, in particular from the estuary of the River Elbe, are presented in a recent paper (Bulnheim, 1978). Findings gained from further experiments (performed at $15^{\circ} \mathrm{C}$ and $10 \% \mathrm{~S}$ ) are included in this report.

Previous detailed studies provided substantial evidence that all Octosporea-infected females obtained from the Elbe estuary gave birth to thelygenic broods under constant laboratory conditions. Only exceptionally did males and intersexes occur: The broods of 13 parasitized females examined were composed of 1029 우, 10 o $\delta$ and 24 intersexes. (These and the following data do not include progeny of $q$ co collected in the field during winter time; see pp. 16-19.)

Most females found to be associated with $T$. herediteria also produced all-female broods. In total, 15 pairs taken from the field yielded 909 o우, $126 \hat{\delta} \hat{\delta}$ and 5 intersexes. However, a few of the animals examined proved to be imperfectly thelygenic females. They gave birth to mixed progeny composed of infected and non-infected females as well as non-infected males. The ratio between $\phi+9$ and $\hat{\delta} \hat{o}$ free of microsporidians was shown to depend on the genetic background and the photoperiod, to which the broods were subjected. The infected young, on the other hand, were demonstrated as not being responsive to different light-dark cycles. During these experiments all offspring of females infested by microsporidians were raised at long-day photoperiods. By means of the numbers of males that appeared in the broods produced, this experimental procedure allowed estimation of the ratio of parasite-free eggs released and discernment of imperfectly from perfectly thelygenic $\$+\$$. Female progenitors were designated as perfectly thelygenic, if less than $10 \%$ males occurred in their progeny.

Generally, females prevailed in imperfectly thelygenic broods which result from a partial infection of the eggs during the oogenesis of the female progenitor. Astonishingly, the sex-ratio condition for imperfect thelygeny as caused by $T$. berediteria was maintained in successive generations and could not be abolished, for instance, by crosses with males of other strains.

Since parasitizations by Octosporea effeminans and Thelohania berediteria have been also detected in other G. $d$. duebeni populations (see Table 5), further breeding experiments were performed with members of some of these populations. Among others, they were concerned with individuals of the "Kleiner Kiel", a brackish-water lake located at Kiel. Two Octosporea-infected 우우 obtained from this locality pro- 
duced almost completely unisexual offspring. By interbreeding with males derived from non-infected parents, one of the two parasitized individuals was used to build up an all-female trait; it was reared over 4 generations. In total, 729 우, 10 , and 2 intersexes derived from this strain.

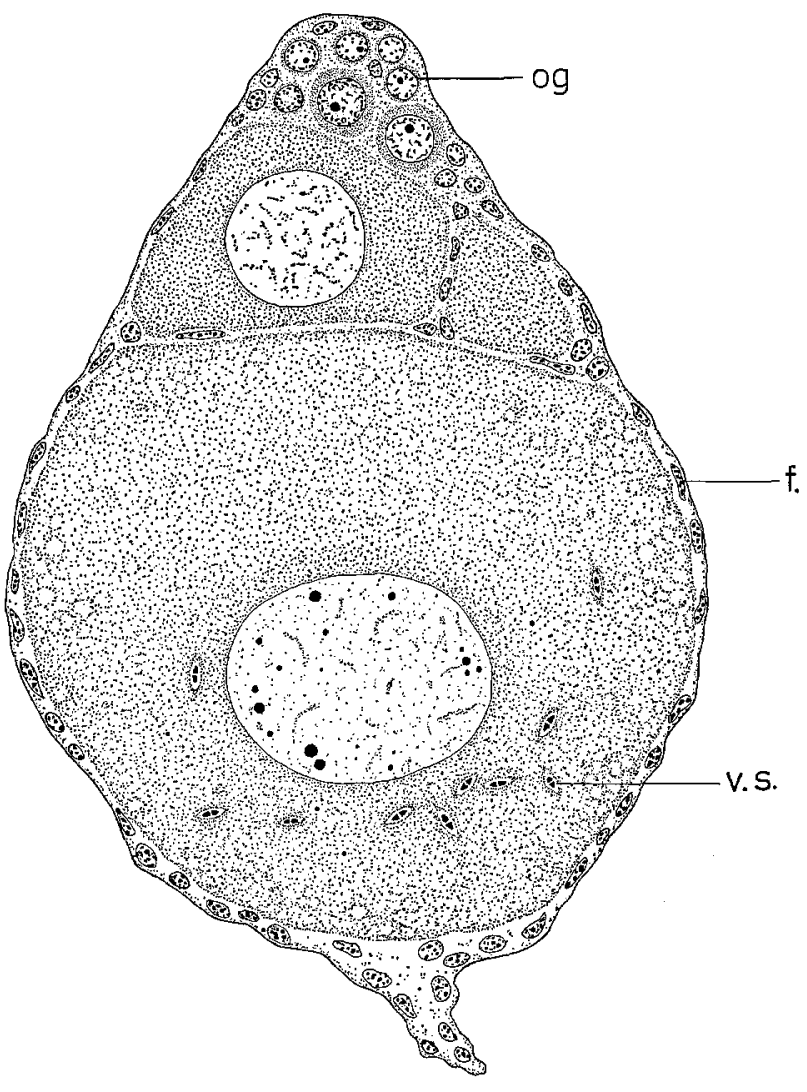

Fig. 2: Transverse section through an ovary (stage $\mathrm{C}$ of the intermoult cycle, prior to yolk deposition) of a Gammarus duebeni duebeni $Q$ infected with Thelohania herediteria. The ovary is composed of oogonia $(\mathrm{og})$ and three layers of oocytes surrounded by follicular cells (f). During the reproductive period these layers comprise small, medium-sized and large oocytes (Le Roux, 1933). Generally, the ooplasm of the latter is infected by vegetative stages (v.s., diplokaryotic meronts). Sporogonic divisions, which give rise to 8 uninucleate spores enclosed by a pansporoblastic membrane, do not occur in the oocytes $(150: 1)$

From a population inhabiting the Baltic Sea Fjord of Schlei progenies produced by 16 Octosporea-infected $q O+$ were examined. Their total sex ratio amounted to 400 우우 : $52 \quad \delta$ o . Several of the parental females were shown to be imperfectly thelygenic. In some cases this could be also demonstrated for their $\mathrm{F}_{2}$-descendants. Comparable to the observations made with offspring of some Thelobania-infected $Q P$ from the Elbe estuary, it could be shown that the percentages of males emerged following 
exposure to long-day photoperiod was largely dependent on the numbers of parasitefree eggs released.

Further, bisexual progeny were also produced by Octosporea-infected $q$ o obtained from a rock-pool population of the northern coastal area of the island of Bornholm. Rearings performed with 10 pairs yielded 224 우, $124 \hat{\delta} \hat{\delta}$ and 1 intersex. Although female descendants predominated, most of the males that emerged were also associated with the microsporidians. In the infected males vegetative stages and spores of O. effeminans were found to be distributed in the testes (Fig. 3). Alterations of their male sex characters did not occur.

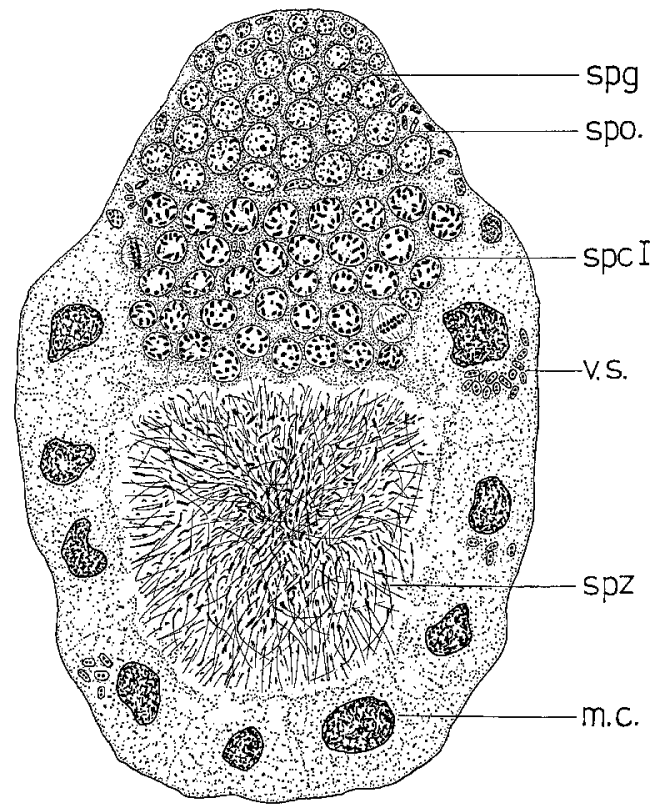

Fig. 3: Transverse section through a testis of a Gammarus duebeni duebeni $\hat{o}$ infected with Octosporea effeminans. Clusters of vegetative stages (v.s., predominantly binucleate meronts) in mucus producing cells (m.c., characterized by large irregularly shaped nuclei) and, associated with spores, in the layers of the spermatogonia (spg) and spermatocytes (spc I, diakinesis and metaphase of the first meiotic division). The microsporidians are not attached to the ripe spermatozoa (spz) $(200: 1)$

By contrast, Thelohania-infected $q Q$ obtained from the same Bornholm population produced only thelygenic broods: 5 pairs gave a total of 179 \&o : $2 \hat{\delta} \delta$; the exceptional males, however, did not harbour the microsporidian parasites.

Thelobania-infected females that were collected in rock pools at Scarlet Point (southern Isle of Man) proved also to be thelygenics. From 7 infected females tested by breeding experiments the progenies obtained were composed of 257 우 : 27 ô $\delta$; one imperfectly thelygenic pair yielded 9 qo $: 10 \hat{\delta} \hat{\delta}$. The males produced were free of microsporidians.

The occasional appearance of Octosporea-infected $\hat{\delta} \hat{\delta}$ as demonstrated for the Bornholm population is regarded as an exception to the rule that the occurrence of 
O. effeminans in G. d. duebeni $q Q+$ is associated with a feminizing influence on their descendants. However, further studies are required to decide, whether or not infected males are also present in populations of other areas.

Moreover, in populations of Gammarus duebeni celticus (from Brasparts, Finistère, and Isle of Man) both sexes were shown to be infested with the two microsporidians under consideration. Even mixed infections occurred in males and females. Although additional proof by breeding experiments is still lacking, this indicates that the parasites produce no effects on sex determination of their host. Alterations of the male sexual phenotype owing to the microsporidian infestations could not be observed either.

As demonstrated by Table 5, a high prevalence of $O$. effeminans and $T$. berediteria was established in the Brasparts population. In $G$. d. celticus individuals obtained from the Isle of Man infestations by $O$. effeminans could not be traced. $T$. herediteria, however, was found parasitic in G. d. celticus females as well as in males derived from Poyllvaaish. This locality is very close to Scarlet Point, from which specimens of $G$. d. duebeni had been collected for the breeding experiments mentioned above. They clearly demonstrated, however, that infections by $T$. herediteria were restricted to the female sex in G. d. duebeni.

\section{ROLE OF ENVIRONMENTAL FACTORS ON THE FEMINIZING EFFECT OF THE MICROSPORIDIANS}

\section{Effects of salinity}

As reported by several studies (cf. Kinne, 1959), the euryhaline amphipod Gammarus duebeni duebeni is able to tolerate a wide range of salinities including sea water. However, its environmental requirements are preferentially met in oligohaline and mesohaline waters. In the field it is normally distributed in salinities between 3 and $12 \%$.

Experiments were undertaken in different salinities in order to explore whether this environmental factor may have any effects on the parasites and thus on sex determination of infected individuals. Previous studies provided evidence that raised salinity levels may exert an influence on sex ratio of progeny produced by $G$. d. duebeni $q O$ (from the Elbe estuary) associated with Octosporea effeminans, but not on progeny of $q$ 우 infested by Thelobania berediteria (Bulnheim, 1969). This became clear when females were exposed to 30 and $35 \% \mathrm{~S}$. Such parasitized individuals were shown to release non-infected eggs which developed into females as well as into males according to genetic and photoperiodic conditions. Thus, as a consequence of the loss of the parasites, a normalization of the mode of sex determination and differentiation could be established. In addition, parasitized broods transferred to $30 \%$ after hatching and raised at long-day photoperiods also developed into females and males.

The studies carried out revealed no adverse effects on $O$. effeminans, when the host was subjected to $20 \%$. With reference to the broad salinity tolerance of $G$. $d$. duebeni, it appeared to be of some interest to find out more precisely the salinity level between 20 and $30 \% \mathrm{~S}$ at which the microsporidians are impaired and, consequently, 


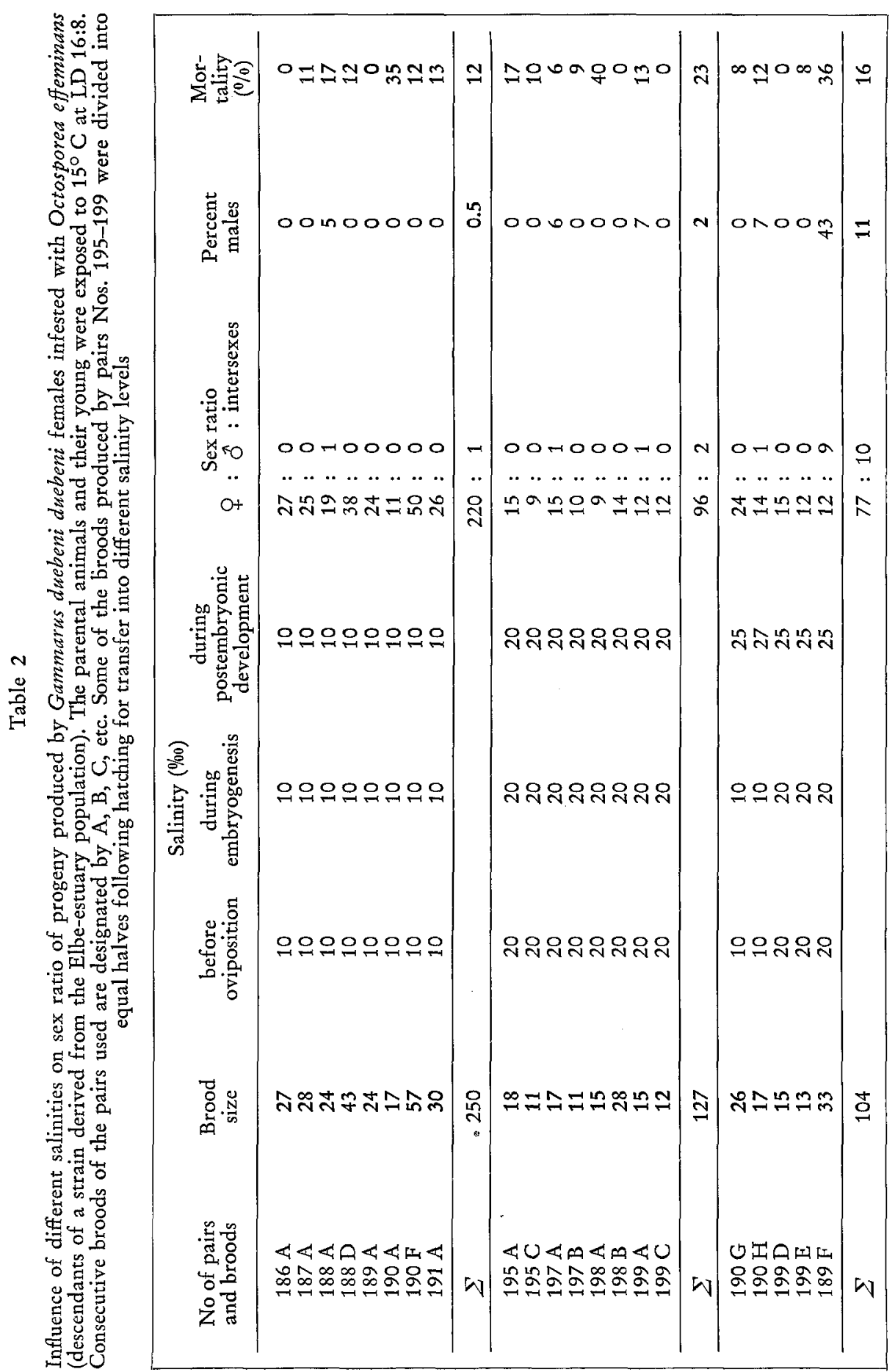




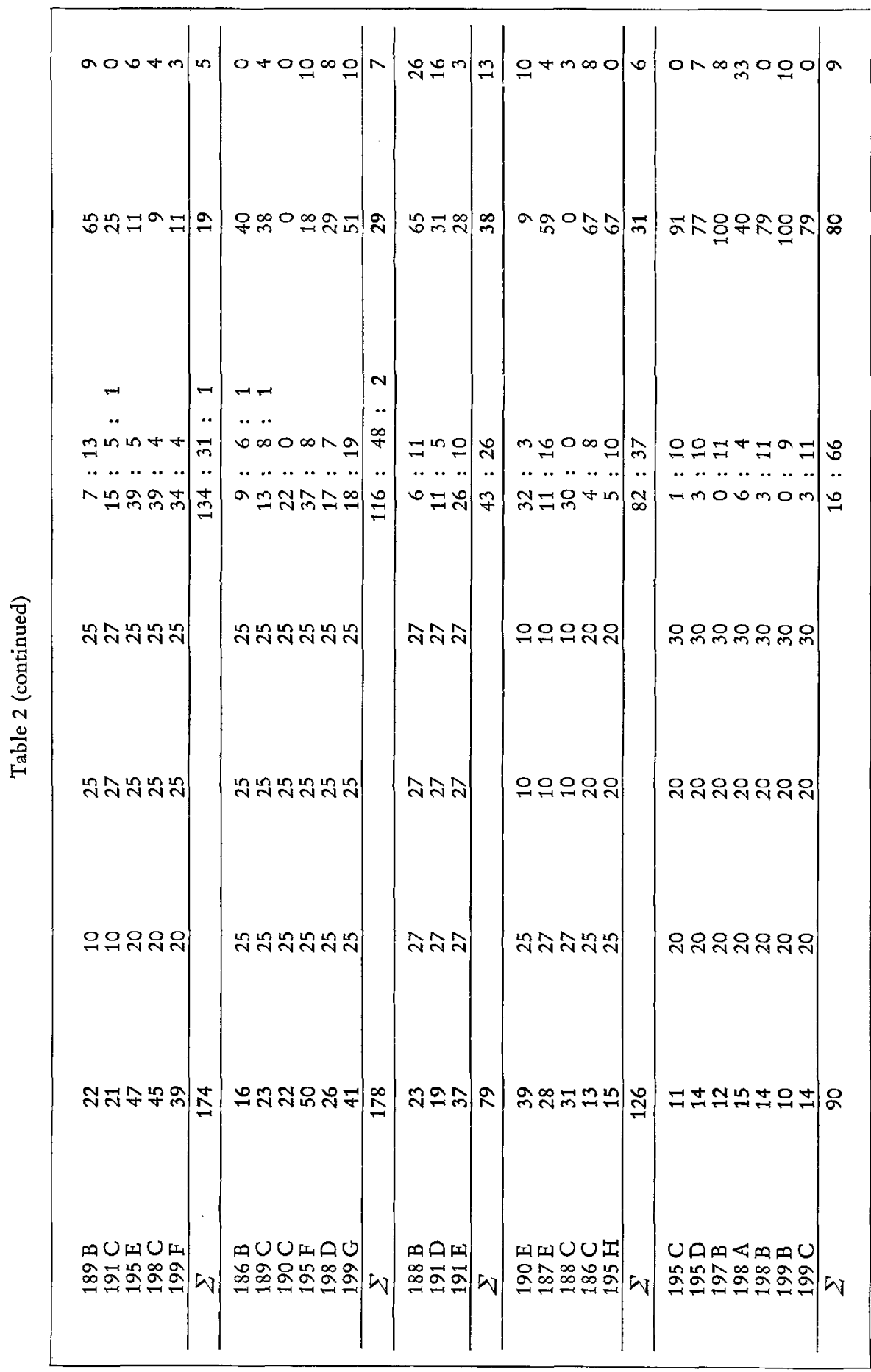


disappear. Therefore, further experiments on their osmotic resistance were conducted including levels of $23,25,27$, and $30 \%$. In these studies, the effects of salinity before oviposition, during embryogenesis, and during postembryonic development were taken into consideration. With reference to the peculiarities of the life cycle of $O$. effeminans in the ovaries (Bulnheim \& Vávra, 1968) it is important to know the developmental stage of the oocytes at which salinity is raised. Investigations on the relationship between onset of the parasitic invasion and the course of oogenesis revealed that infestations of the oocytes by the vegetative stages are primarily confined to the intensive ooplasmic growth phase until cytoplasm is transformed into yolk granules during vitellogenesis; as a rule, the invasion takes place during that intermoult period which precedes deposition of these oocytes following ecdysis.

The results of the pair matings set up with females infected by O. effeminans are listed in Table 2. Whereas no effects could be observed at 10 and $20 \%$ (controls) as well as at $23 \% \mathrm{~S}$ (results not included in Table 2), a shift of sex ratio in favour of the males occurred at higher levels, indicating a critical range between 25 and $30 \% \mathrm{~S}$.

Following an elevation of ambient salinity level to 25 or $27 \%$ during postembryonic development, a slight increase in the numbers of males could be stated. Provided that the elevation of salinity to 25 or $27 \% 0$ was accomplished during embryogenesis and maintained at these levels after hatching, a further shift of sex ratio towards the males was noted. If the critical stage of oogenesis was also included in the exposure to 25 or $27 \%$, the increase of males was more pronounced. A transfer to 20 or $10 \% \mathrm{~S}$ during embryogenesis and postembryonic development, provided that the elevated salinity levels were maintained during oogenesis, gave results comparable to those of the foregoing experimental procedure. An exposure of the broods during postembryonic development to $30 \% \mathrm{~S}$, however, yielded an excess of males (Table 2).

From these findings on sex-ratio alterations it can be concluded that the impairment of $O$. effeminans is not only dependent on the salinity level chosen but also, to some extent, on the developmental stages (oogenesis, embryogenesis, postembryonic development) which, in different combinations, were subjected to the critical salinities of 25 and $27 \%$. The impairment of the parasites increases continuously with raising salinities from 25 to $30 \%$ leading to their disappearance in the eggs laid at $30 \%$. This is, of course, reflected by a significant shift of sex ratio in favour of the males provided that the young which developed from such eggs are raised under long-day photoperiods.

With respect to the osmoconcentrations of the host's body fluids surrounding the parasites, the actual salinity tolerance of $O$. effeminans almost corresponds to the external salinity values that are presented above. In salinities below 12-15\%, G. duebeni is a hyperosmotic regulator; in more concentrated media it is an osmo-conformer (cf. Kinne, 1959).

Finally, an attempt was made to examine the relationship between exposure time to the elevated salinity level and the degree of impairment of the parasites. This experiment was confined to a microscopic control of the eggs produced during subsequent ovipositions after having subjected Octosporea-infected $\$$ 우, which were reared in $10 \% \mathrm{~S}$, to $30 \% \mathrm{~S}$ for a certain period of time. It ranged from 52 to 70 days at $15^{\circ} \mathrm{C}$, which corresponds to about 2 to 3 intermoult periods at the given temperature. There- 
after, the test animals were re-transferred to $10 \% \mathrm{~S}$. In order to record the occurrence of vegetative stages at successive ovipositions, all eggs released into the brood pouch of the females were microscopically examined following acetocarmine staining.

Table 3

Occurrence of vegetative stages in the eggs at successive ovipositions following transfer of Gammarus duebeni duebeni females infested with Octosporea effeminans from $30 \%$ (temporary exposure) to $10 \% \mathrm{~S}$ at $15^{\circ} \mathrm{C}$. - no infection; \pm eggs partially infected; + all eggs infected

\begin{tabular}{|c|c|c|c|c|c|c|}
\hline \multirow{2}{*}{$\begin{array}{c}\text { No } \\
\text { of } 9 \text { 우 }\end{array}$} & \multirow{2}{*}{$\begin{array}{c}\text { Days of exposure } \\
\text { to } 30 \% 0 \mathrm{~S}\end{array}$} & \multicolumn{5}{|c|}{ Ovipositions following transfer to $10 \% \mathrm{~S}$} \\
\hline & & 1. & 2. & 3. & 4. & 5. \\
\hline 1 & 52 & - & & \pm & & \\
\hline 2 & 52 & & - & $=$ & - & \\
\hline 3 & 67 & - & & - & & \\
\hline 4 & 70 & & - & - & \pm & + \\
\hline 5 & 54 & - & & & $\overline{ \pm}$ & \\
\hline 6 & 61 & - & \pm & & & \\
\hline 7 & 59 & - & \pm & \pm & \pm & \\
\hline 8 & 61 & & \pm & \pm & & \\
\hline 9 & 61 & - & - & \pm & + & \\
\hline 10 & 55 & - & - & & & \\
\hline
\end{tabular}

As expected, the eggs deposited at the first oviposition following re-transfer to $10 \% \mathrm{~S}$ were all free of parasites (Table 3), since the adverse influence of the raised salinity was still effective during that stage of oogenesis (cytoplasmic growth phase prior to vitellogenesis) at which the microsporidians normally invade the oocytes. Beginning with the second oviposition at $10 \% \mathrm{~S}$, some eggs laid by 3 of 7 test animals could be established as infected, indicating a temporary inactivation and subsequent recovery of the parasites in their host. At the fourth and fifth oviposition following transfer to $10 \% \mathrm{~S}$ all eggs released proved to be infected except for those of one female which, at the beginning of the experiment associated with the parasites, produced eggs exclusively free of microsporidians. This demonstrates that an exposure to $30 \%$ during a 2 -month period generally does not yet cause an irreversible impairment of O. effeminans.

The results obtained can be incorporated into previous findings about the influence of a temporary salinity rise on the development of Octosporea-infected young into various degrees of intersexes (Bulnheim, $1975 \mathrm{a}$ ). If they were subjected to $30 \% \mathrm{O}$ for certain periods of time after hatching, intersexual individuals, which normally appear in rather low numbers, increased significantly. This development can be ascribed to a temporary, salinity-induced impairment of the microsporidians. Following a re-transfer into lower salinities the parasites recovered in most cases and regained their feminizing effect upon the host. If sex differentiation was directed to maleness, further development could proceed into various degrees of intersexuality. In general, the later this feminizing influence became effective during ontogeny, the stronger was the masculine expression of the intersexual phenotypes.

Concluding from the findings reported in this chapter, it appears that the increase 
of the intracellular and extracellular osmoconcentrations in the tissues of the host following an elevation of external salinity inhibits the multiplication of the vegetative stages and probably any processes associated with the merogonial life cycle of O. effeminans which might be of importance for the actions on the host. Hence, the parasites can no longer exert a sex-determining influence. This is indicated by the sexual development of infected young exposed to $30 \% \mathrm{~S}$ after hatching. Although most of them are likely to be still infested with the microsporidian at the onset of and during sex differentiation, its feminizing influence on the host does not become effective, apparently induced by the failure to undergo schizogony.

\section{Effects of temperature}

In a second experimental series the influence of temperature on sex ratio of infected females was tested in a similar manner as outlined in the foregoing chapter dealing with the study on the effects of various salinity levels.

The role of temperature on sex determination of Gammarus duebeni has been a controversial subject for some time. Working with individuals from the brackish-water lake "Kleiner Kiel", Kinne (1952, 1953, 1961) reported an influence of temperature on sex ratio of progenies. He found that parents kept in temperatures below $5^{\circ} \mathrm{C}$ gave rise only to $\delta^{\lambda} \delta$, whereas parents kept in temperatures above $8^{\circ} \mathrm{C}$ produced only $q$ 우; between $5^{\circ}$ and $8^{\circ} \mathrm{C}$ broods were composed of both sexes. Kinne supposed the temperature-sensitive phase to be restricted to a certain period of oogenesis prior to oviposition (corresponding to the terminal period of vitellogenesis).

Traut (1960,1962), on the other hand, did not find an influence of temperature on sex determination in G. duebeni. Rather, he provided evidence for a maternallyinherited thelygeny in several females derived from the populations of the "Kleiner Kiel " and the Elbe estuary. Kinne also observed such monogeny phenomena but owing to his short-term experiments he interpreted the observations made as responses to the various temperature regimes tested. Actually, Octosporea-infected $q Q$, that were shown to produce all-female broods in the laboratory, could be detected later in the "Kleiner Kiel" (see Table 5). It is probable, therefore, that Kinne had used infected test animals, which were not recognized by him, since they cannot be discerned macroscopically from individuals free of the microsporidians under consideration.

Concerning the role of temperature the results obtained in this study are in accordance with 'Traut's findings only in regard to non-infected individuals: A great number of experiments conducted at different temperatures $\left(4^{\circ}-15^{\circ} \mathrm{C}\right)$, to which parents from non-infected strains (from the Elbe estuary) were exposed during various stages of oogenesis and embryonic development, did not demonstrate any thermal influence on sex ratio.

Proceeding from some observations made on the temperature-sensitivity of the life cycle of certain microsporidian species (cf. Weiser, 1976), the influence of low temperatures on females infested by Octosporea effeminans and Thelobania berediteria was tested. With regard to the invasion of the oocytes by the parasites in the course of the previtellogenic growth phase, the effects of exposures to different tempera- 
tures were examined during the intermoult period prior to oviposition. Some results of this experiment carried out with females from perfectly thelygenic strains are shown in Table 4. They indicate that in some (not in all) Octosporea-infected 우 an exposure to $3^{\circ}, 4^{\circ}$ and exceptionally to $6^{\circ} \mathrm{C}$ before oviposition may lead to some alteration in sex ratio of their respective broods in favour of males. The descendants that revealed a slight shift of sex ratio developed from oocytes which were subjected to lowered temperatures during the phases of previtellogenesis and vitellogenesis in the intermoult period before being released as ripe eggs. At $15^{\circ} \mathrm{C}$ only all-female offspring were produced. The unisexual condition was also maintained following an exposure to $8^{\circ}$ and $6^{\circ} \mathrm{C}$ before deposition of the eggs. However, if the females examined were exposed to $3^{\circ}$ or $4^{\circ} \mathrm{C}$ for one or two intermoult periods before having been transferred to $6^{\circ}$ or $8^{\circ} \mathrm{C}$ they, in some cases, also gave birth to a few male young. Summing up all data listed in Table 4 , an exposure of the test animals to $3^{\circ}$ or $4^{\circ} \mathrm{C}$ prior to oviposition resulted in sex ratios of 47 우 : $45 \hat{\delta} \hat{\delta}$ (Strain M I) and 50 우우 : 10 oै $\delta$ (Strain M II).

To some extent, temperature-sensitivity could also be demonstrated for Thelobania-infected individuals. Only few results were obtained, which are included in Table 4. Pooling all data, an exposure of the females examined to $3^{\circ}$ or $4^{\circ} \mathrm{C}$ prior to oviposition gave a sex ratio of their respective broods of 68 우 : $32 \hat{\delta} \hat{\delta}: 1$ intersex, whereas an exposure to $8^{\circ} \mathrm{C}$ resulted in 191 우 $: 15 \hat{o} \hat{o}$.

Complementary microscopic examinations of the eggs deposited after treatments at lowered temperatures revealed that not all of them were infected. As a consequence of the temperature decline some of the growing oocytes do not become parasitized; it appears that merogony is retarded. Although a thermal cure of the infected mothers cannot be achieved, their descendants, to a certain degree, may be liberated from the parasites and thus from their feminizing influence.

From the results obtained temperature sensitivity of the microsporidians cannot be clearly defined in terms of a distinct temperature level. In some instances no effects could be noted following an exposure to $4^{\circ}$ or $3^{\circ} \mathrm{C}$. Also, infected females collected in the field during winter time, whose progeny were reared in the laboratory at $15^{\circ} \mathrm{C}$, did not regularly give rise to mixed offspring. In contrast to the effects observed following exposures to elevated salinities, low temperatures only become effective during oogenesis, when the invasion of the oocytes by the parasites takes place. The experiments carried out indicated the necessity of subjecting infected females to the low temperature regime during the whole intermoult period preceding oviposition in order to produce some alteration in sex ratio of their progeny; at $4^{\circ} \mathrm{C}$ this period comprises ca. 3 months; short-term treatments at this level were not effective. An exposure to $15^{\circ} \mathrm{C}$ in the course of oogenesis and embryogenesis followed by a transfer to $4^{\circ} \mathrm{C}$ during the period from hatching to sex differentiation did not affect the feminizing influence of the microsporidians on the progeny.

In an additional experiment performed with Octosporea-infected $q 09$ an attempt was made to test the influence of temperatures elevated to $22^{\circ}$ and $25^{\circ} \mathrm{C}$. Generally, above $20^{\circ} \mathrm{C}$ no more eggs are deposited and mortality increases. An exposure of the test animals to these temperatures up to 4 weeks did not affect the parasites. Following transfer to $15^{\circ} \mathrm{C}$, most eggs laid were shown to be infected. 
Table 4

Influence of various temperatures (at $10 \% \mathrm{~S}$ ) on sex ratio of progeny from Gammarus duebeni duebeni females (laboratory-reared strains, derived from the Elbe-estuary population) infested with Octosporea effeminans or Thelobania berediteria. Offspring were exposed to $15^{\circ} \mathrm{C}$ and LD 16:8 at 10\%0 S. Consecutive broods of the pairs used are designated by $\mathrm{A}$, $\mathrm{B}, \mathrm{C}$, etc.

\begin{tabular}{|c|c|c|c|c|c|}
\hline $\begin{array}{l}\text { No of pairs } \\
\text { and broods }\end{array}$ & $\begin{array}{c}\text { Brood } \\
\text { size }\end{array}$ & $\begin{array}{l}\text { Temp } \\
\text { before } \\
\text { ovi- } \\
\text { position }\end{array}$ & $\begin{array}{l}\text { ure }\left({ }^{\circ} \mathrm{C}\right) \\
\text { during } \\
\text { embryo- } \\
\text { genesis }\end{array}$ & 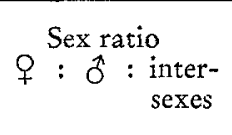 & $\begin{array}{l}\text { Mor- } \\
\text { tality } \\
(\% / 0)\end{array}$ \\
\hline \multicolumn{6}{|c|}{ Strain M I infested with Octosporea effeminans } \\
\hline $117 \mathrm{~A}$ & 0 & 3 & 3 & & \\
\hline B & 25 & 3 & 6 & $14: 4$ & 28 \\
\hline $\mathrm{C}$ & 48 & 6 & 8 & $22: 20$ & 13) \\
\hline $\mathrm{D}$ & 45 & 8 & 8 & $41: 1$ & 7 \\
\hline $\mathrm{E}$ & 45 & $4+8$ & 8 & $43: 0$ & 4 \\
\hline $118 \mathrm{~A}$ & 8 & 3 & 3 & $5: 0$ & 38 \\
\hline B & 0 & 3 & 6 & & \\
\hline $\mathrm{C}$ & 14 & 6 & 6 & $8: 0$ & 43 \\
\hline $\mathrm{D}$ & 17 & 6 & 4 & $12: 0$ & 29 \\
\hline $123 \mathrm{~A}$ & 0 & 3 & 3 & & \\
\hline & 50 & 6 & 6 & $29: 19$ & 2 \\
\hline $\mathrm{C}$ & 51 & 6 & 4 & $24: 25$ & 4 \\
\hline $\mathrm{D}$ & 48 & 4 & 8 & $18: 25$ & 10 \\
\hline$\overline{\mathrm{E}}$ & 48 & 8 & 8 & $27: 7$ & 29 \\
\hline$\vec{F}$ & 51 & 8 & 8 & $18: 3$ & 59 \\
\hline $127 \mathrm{~A}$ & 26 & 15 & 3 & $6: 0$ & 77 \\
\hline & 13 & 3 & 3 & $2: 11$ & 0 \\
\hline C & 45 & $3+6$ & 6 & $20: 23$ & 4 \\
\hline $\mathrm{D}$ & 41 & 6 & 4 & $6: 7$ & 68 \\
\hline $130 \mathrm{~A}$ & 11 & 15 & 3 & $9: 0$ & 18 \\
\hline & 17 & 3 & 3 & $8: 5$ & 24 \\
\hline C & 0 & 3 & 6 & & \\
\hline $\mathrm{D}$ & 32 & 6 & 4 & $21: 11$ & 0 \\
\hline $\mathrm{E}$ & 0 & 6 & 6 & & \\
\hline$F$ & 50 & 6 & 12 & $27: 5$ & 36 \\
\hline \multicolumn{6}{|c|}{ Strain M II infested with Octosporea effeminans } \\
\hline $893 \mathrm{~A}$ & 7 & 15 & 15 & $7: 0$ & 0 \\
\hline B & 26 & 15 & 4 & & 100 \\
\hline $\mathrm{C}$ & 46 & 4 & 4 & $19: 9$ & 39 \\
\hline $894 \mathrm{~A}$ & 26 & 15 & 15 & $26: 0$ & 0 \\
\hline B & 42 & 15 & 6 & $38: 3$ & 2 \\
\hline C & 58 & 6 & 6 & $44: 7$ & 12 \\
\hline $\mathrm{D}$ & 73 & 6 & 6 & $68: 0$ & 7 \\
\hline $895 \mathrm{~A}$ & 34 & 15 & 15 & $34: 0$ & 0 \\
\hline B & 31 & 15 & 4 & $22: 0$ & 29 \\
\hline $\mathrm{C}$ & 9 & 4 & 4 & $5: 1$ & 33 \\
\hline $\mathrm{D}$ & 27 & 4 & 15 & $26: 0$ & 4 \\
\hline $898 \mathrm{~A}$ & 15 & 15 & 15 & $14: 0$ & 7 \\
\hline B & 54 & 15 & 6 & $50: 0$ & 7 \\
\hline C & 47 & 6 & 6 & $40: 2$ & 11 \\
\hline $\mathrm{D}$ & 86 & 6 & 15 & $86: 2$ & 0 \\
\hline $\mathrm{E}$ & 9 & 15 & 15 & $9: 0$ & 0 \\
\hline
\end{tabular}


Table 4 (continued)

\begin{tabular}{|c|c|c|c|c|c|c|}
\hline $\begin{array}{l}\text { No of pairs } \\
\text { and broods }\end{array}$ & $\begin{array}{c}\text { Brood } \\
\text { size }\end{array}$ & $\begin{array}{l}\text { Tempe } \\
\text { before } \\
\text { ovi- } \\
\text { position }\end{array}$ & $\begin{array}{c}\text { re }\left({ }^{\circ} \mathrm{C}\right) \\
\text { during } \\
\text { embryo- } \\
\text { genesis }\end{array}$ & $q^{s}$ & $\begin{array}{l}\text { Sex ratio } \\
: \delta: \begin{array}{l}\text { inter- } \\
\text { sexes }\end{array}\end{array}$ & $\begin{array}{c}\text { Mor- } \\
\text { tality } \\
(0 \%)\end{array}$ \\
\hline \multicolumn{7}{|c|}{ Strain infested with Thelohania berediteria } \\
\hline $137 \mathrm{~A}$ & 0 & 3 & 3 & & & \\
\hline B & 21 & 3 & 8 & 12 & $: 3: 1$ & 24 \\
\hline C & 32 & 8 & 8 & 29 & $: 0$ & 9 \\
\hline D & 26 & 8 & 4 & 20 & $: 4$ & 8 \\
\hline $140 \mathrm{~A}$ & 0 & 3 & 3 & & & \\
\hline B & 49 & 8 & 4 & 34 & $: 4$ & 22 \\
\hline $\mathrm{C}$ & 56 & 4 & 8 & 36 & $: 9$ & 20 \\
\hline D & 43 & 8 & 8 & 38 & $: 0$ & 12 \\
\hline $\mathbf{E}$ & 45 & 8 & 8 & 40 & $: 1$ & 9 \\
\hline $143 \mathrm{~A}$ & 0 & 3 & 3 & & & \\
\hline B & 43 & 3 & 8 & 20 & $: 20$ & 7 \\
\hline C & 46 & 8 & 8 & 20 & $: 4$ & 48 \\
\hline $\mathrm{D}$ & 19 & 8 & 4 & 10 & $: 2$ & 37 \\
\hline
\end{tabular}

\section{MICROSPORIDIOSES IN VARIOUS POPULATIONS}

Gammarus duebeni is widespread in western and northern Europe and along the Atlantic coasts. In order to gain some information on the occurrence of the microsporidians Octosporea effeminans and Thelobania berediteria and incidence rates in various $G$. dnebeni populations, samples were taken from a wide geographical range. In total, $15 G$. d. duebeni and $3 G$. d. celticus populations from various localities were studied from 1965 to 1977 . The results of these microscopic investigations are summarized in Table 5.

Only few of the populations tested have been found to be free of microsporidians; however, as the sizes of various samples taken are not very large, definite conclusions cannot be drawn. Members of several populations harbour either Octosporea effeminans, Thelohania berediteria, or Stempellia mülleri. The latter microsporidian, recently named Microsporidium giraudi (Léger \& Hesse) by Sprague (1977), does not affect sex determination and differentiation of its host. Invading the abdominal muscles, it is also parasitic in several other Gammarus species (Bulnheim, 1971b). Among the $G$. d. duebeni populations examined, relatively high incidence rates of O. effeminans were recorded from females collected in the Fjord of Schlei. Also, a high prevalence of $O$. effeminans and $T$. berediteria could be established in members of a $G . d$. celticus population occurring at Brasparts (France). Here, several dual infections have been found too. Mixed infections, however, were rare in G. d. duebeni; among 865 females examined from the Elbe estuary, two individuals proved to be associated with both microsporidians.

As outlined above, only few populations have been studied to ascertain whether or not and to what extent sex ratio of the progeny of the host is affected by the parasitic infestations. Besides breeding experiments this information can also be made 
H.-P. Bulnheim



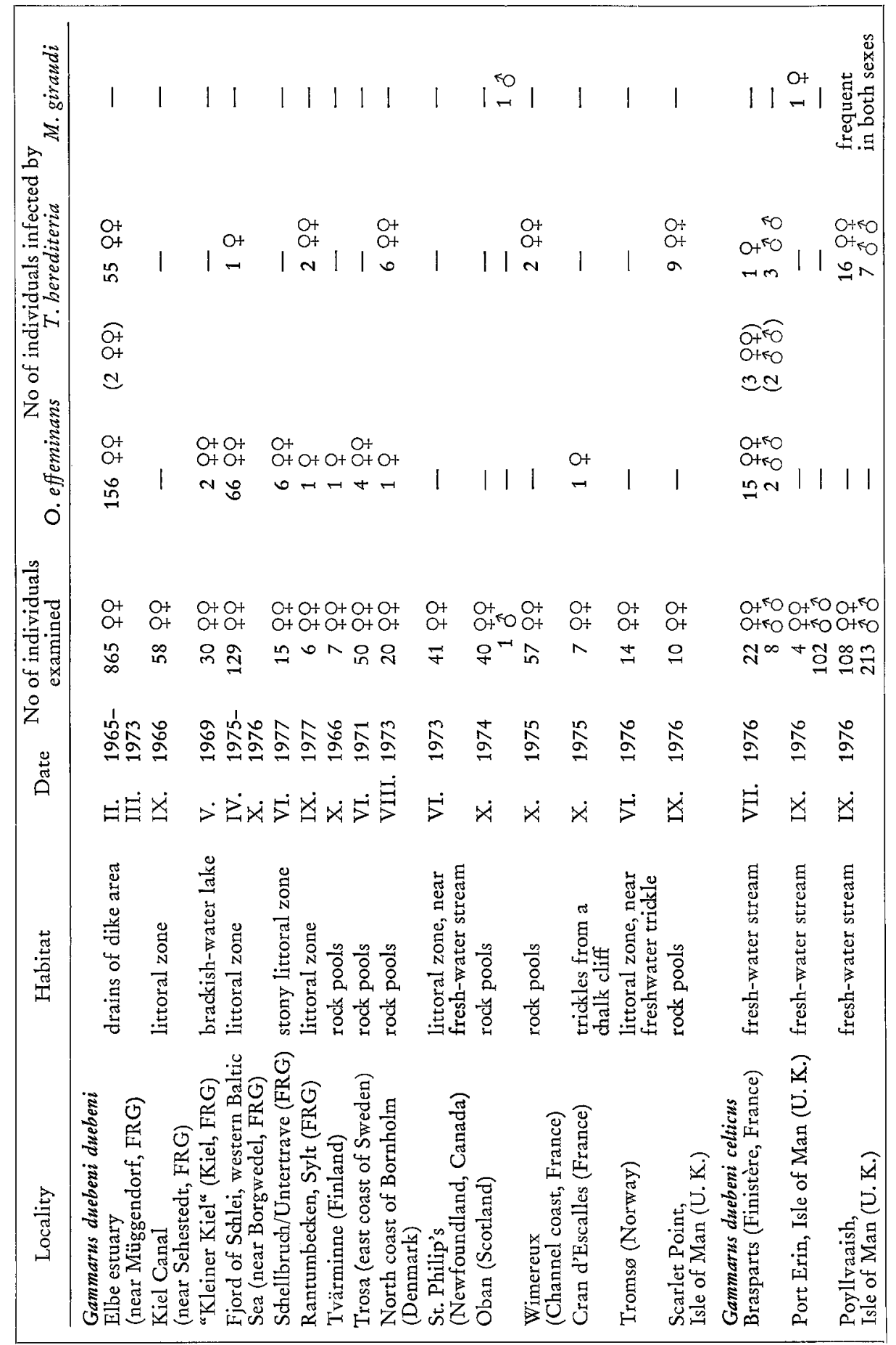




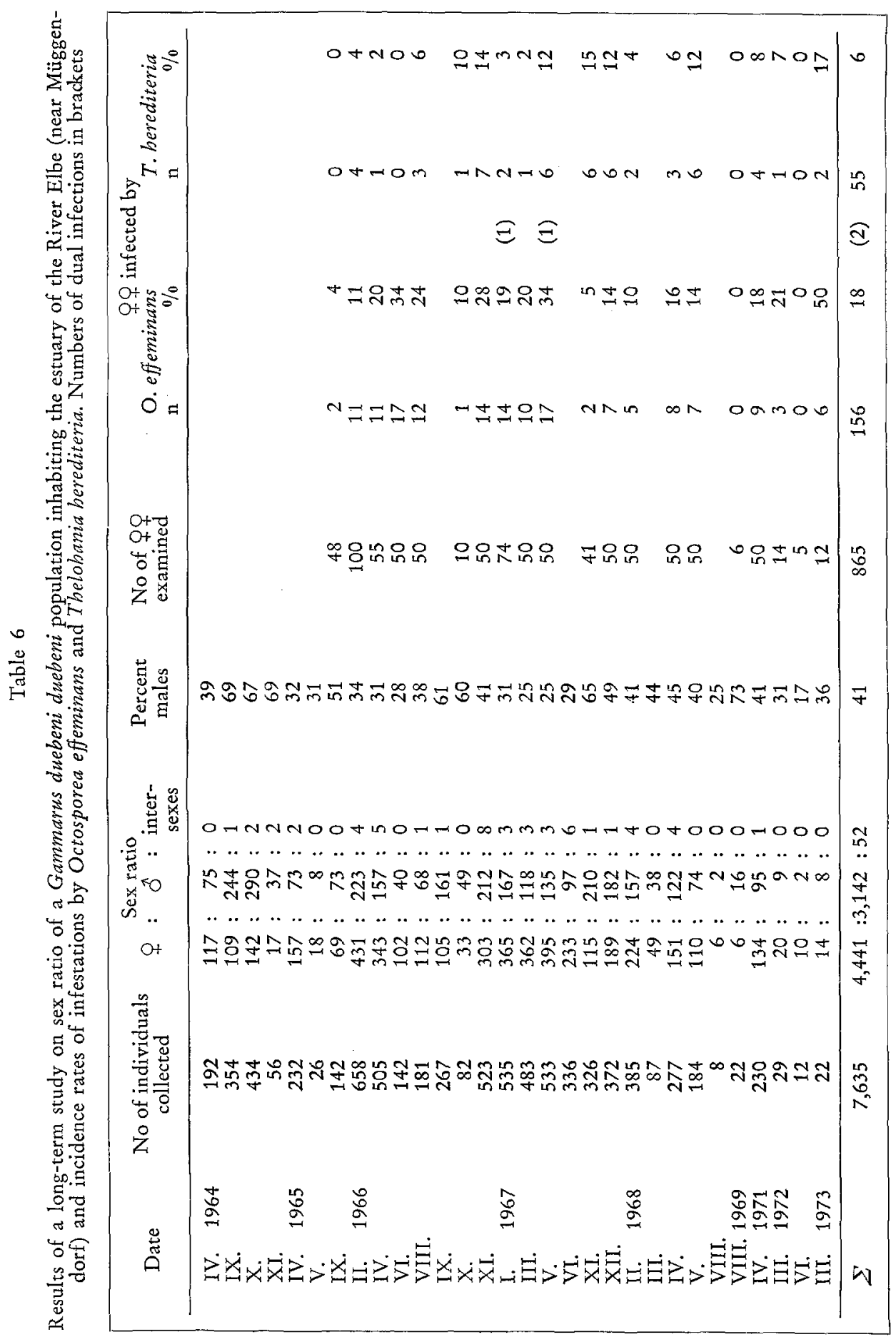


accessible by examining sufficient numbers of males. Since the absence of feminizing effects by $O$. effeminans and $T$. herediteria has been detected in $G, d$. celticus by more recent observations, previous studies (except for the G. $d$. duebeni populations of the Elbe estuary, "Kleiner Kiel" and Schlei which gave negative results) were not extended to males for furnishing proof of an absence or presence of microsporidian infestations.

Taken all together, the findings summarized in Table 5 indicate that the microsporidian parasites associated with $G$. duebeni are rather widespread in their geographical range, although local differences may exist. However, in most G. d. duebeni populations studied, the incidence rates of infected females do not go beyond $50 \%$.

\section{SEX RATIOS IN THE FIELD}

Parallel to experiments conducted in the laboratory a series of observations was made in the field in order to find out to which degree fluctuations of sex ratio occur. To this end the Gammarus duebeni duebeni population inhabiting the estuary of the River Elbe (near Müggendorf) was studied from 1964-1973. Table 6 presents the sex ratios of the individuals collected ( $>8 \mathrm{~mm}$ body length) and the incidence rates of infected females as estimated from different-sized samples taken.

The variations of sex ratios are rather well illustrated by the data presented for 5 succeeding years from 1964-1968. Whereas, during the study period in the first halves of the years under consideration, the females predominated, the number of males increased during the second annual halves and reached maxima in autumn. This pattern of annual fluctuation appeared to occur regularly. The percentage of males ranged from about $30 \%$ to more than $60 \%$.

In addition, the percentages of $q$ 우 infected by Octosporea effeminans and Thelobania herediteria were also found to be subject to some fluctuation. Infections by $O$. effeminans occurred at higher frequencies than those by $T$. berediteria: The mean incidence of microsporidian infection in females amounted to $18 \%$ by O. effeminans and $6 \%$ by $T$. herediteria. The rates of infestations, however, displayed no tendency to rise during the observation period.

For an interpretation of the fluctuation of sex ratio several factors must be taken into account. Comparable to observations made on the life cycle of populations from several other localities (cf. Kinne, 1959), length of life is almost annual in the G.d. duebeni population of the Elbe estuary. On the average, males have a longer life span than females and are less sensitive to adverse environmental conditions. Furthermore, the reproductive resting stage of the females occurring in late summer and autumn, which involves a cessation of egg production, must be taken into consideration as well as the dependence of oviposition intervals and growth rates of the young on the seasonal alterations of temperature.

Evidently, the fluctuations of sex ratio observed reflect the influence of different photoperiods that are accompanied with the seasonal changes. The rise in the percentages of males before and during fall is in fairly good correspondence with the long-day photoperiods acting from spring to summer time. With regard to the critical photo- 
period, the conditions for a shift of sex ratio in favour of the males become effective during April in this locality.

Although, as a consequence of the decline of water temperatures, which are generally below $4^{\circ} \mathrm{C}$ between December and March in the study area, oviposition intervals are considerably prolonged and hence the productivity of the population is low, the fall of temperatures in winter may contribute to a certain decrease of infections in the young produced by parasitized females. Findings obtained from offspring of infected oq collected in the field during winter time and raised in the laboratory at higher temperatures support this assumption: in some cases, a reversal from mixed progeny to thelygeny could be observed in successive broods.

Salinity can be neglected as a regulating factor for sex ratio in the population studied, since $20 \% \mathrm{~S}$ is not exceeded in this estuarine locality. In summary, despite seasonal fluctuations, the proportions of females to males remained at a fairly balanced level during the observation period.

Since 1972 population density has decreased in the study area of the Elbe estuary. The reason could not be clearly recognized. It is possible that the reinforcements of the dikes which were improved at that time may have contributed to this decline. However, with some degree of certainty, the above reported data indicate that a significant increase of infected 우 associated with a numerical decrease of $\hat{o} \hat{\delta}$ can be excluded as responsible for this alteration.

\section{DISCUSSION}

The general picture of sex determination in Gammarus duebeni that emerged from this study and previous investigations is somewhat complex. Genetic and various nongenetic factors have been demonstrated to be involved and, integrated into a hierarchically organized system, to play a direct or indirect role as sex determinants.

\section{Role of genetic factors and photoperiod}

In the Gammarus duebeni duebeni strains used for studies on the influence of photoperiod on sex ratio genetic factors appear to have no strong influence on sex determination. Previous studies provided evidence neither for the occurrence of sexlinked inheritance nor for the existence of heteromorphic sex chromosomes (Traut, 1962; Bulnheim, 1965)). In accordance with the interpretation given by Traut (1962), who suggested polygenic sex determination in $G$. duebeni, an almost balanced polyfactorial system of opposing sex genes is supposed to operate. The number of loci with additive male and female alleles acting in this system is not known. However, though more information on the genetic background is needed, models proposed for other labile gonochorists and unbalanced hermaphrodites in order to explain the sex variability observed (Bacci, 1965) may provide a general scheme of interpretation.

The marked variability of sex ratio inherent to polygenic sex determination can be expected to be modified by environmental factors as has been demonstrated for 
photoperiod. Generally, in the broods produced by uninfected parental animals there is a fairly high number of young whose sex realization is dependent on the daylength which they are subjected to. Corresponding to the polygenic interpretation of sex determination, their genetic constitution appears to be nearly balanced in terms of quantitative effects exerted by male and female deciding genes. However, among the multiple sex genotypes which can be assumed to exist some may occur that do not attain the certain degree of genetic equilibrium necessary for a susceptibility to photoperiodic influences. Under such conditions, genetic factors will govern the direction of the sexual development. Corresponding to this view, the few males generally raised under shortday conditions and the few females generally emerged under long-day conditions are regarded to arise due to more stable sex genotypes.

Evidence for a control of reproductive processes by photoperiod has also been provided in some other crustaceans. With reference to sex determination and differentiation Becker-Carus (1967) observed a shift of sex ratio after having imposed different light-dark cycles on the progeny of pairs derived from certain strains of the isopod Armadillidium vulgare. Unlike Gammarus duebeni duebeni, males prevail under shortday photoperiod (LD $8: 16$ ), while females dominate under long-day photoperiod (LD $16: 8$ ). In Gammarus zaddachi a shift of sex ratio in favour of the males was noted following exposure of the broods to long-day photoperiod (Bulnheim, 1972) but, compared to G.d.duebeni, the responses to different photoperiods were less pronounced. Legrand-Hamelin \& Mocquard (1976) recorded an increase of intersexes in certain crosses performed with Idotea baltbica following an exposure of the descendants to long-day photoperiod (LD $18: 6$ ).

In cladocerans reproduction and diapause induction is also under the control of photoperiod interacting with population density and other extrinsic factors. The transitional reversal from parthenogenesis to bisexual reproduction in Daphnia pulex is promoted by a critical photoperiod of LD $12.75: 11.25$ at $19^{\circ} \mathrm{C}$ (Stross \& Hill, 1968): The critical daylength is influenced only slightly by temperature; at $12^{\circ} \mathrm{C}$ it is LD $13: 11$. Compared to the reproductive shift in $D$. pulex (at $45^{\circ} \mathrm{N}$ ), Stross (1969) found a much longer critical photoperiod of LD $22: 2$ in an arctic population of D. middendorffiana $\left(\right.$ at $71^{\circ} \mathrm{N}$ ). As known from other arthropods at mid and high latitudes, this provides additional evidence for a latitudinal adaptation of critical daylength. Whether or not the critical daylength of the photoperiodic response established in the G. $d$. duebeni population of the Elbe estuary $\left(\right.$ at $53.8^{\circ} \mathrm{N}$ ) varies in other geographical populations requires further analysis.

In contrast to the rather well-documented insect photoperiodisms only little information on photo-induced processes is available in crustaceans. In addition, there is fragmentary understanding about the specific physiological mechanisms by which photoperiodic stimuli influence the pathways of differentiation. It has been suggested that the neurosecretory system mediates the photoperiodic response and is involved in the control of the differentiation of the androgenic glands (Bulnheim, 1967). Acting as hormonal effectors, they play a key position in male sex differentiation of the Malacostraca as demonstrated by studies especially in Orchestia; androgenic gland anlagen are found in all young after hatching. In those which are genetically males they develop into functional glands and cause the undifferentiated gonads to become testes. 
In young which are genetically females the androgenic anlagen do not develop and the gonads differentiate into ovaries (cf. Charniaux-Cotton, 1972).

\section{Monogeny and effects of environmental factors}

The thelygeny phenomena as caused by hereditary microsporidian infections in Gammarus duebeni duebeni are rather peculiar expressions of specific host-parasite interactions. Among the array of various pathogenic effects known to be produced by microsporidians, an affection of determination and inheritance of sex of the host has not been previously detected. Both parasites, Octosporea effeminans and Thelohania berediteria, are completely integrated into their host and its reproductive cycle. Resulting from the feminizing effect exerted by the two microsporidians under consideration, the normally acting switch-mechanism of sex determination is overruled. This became clear by the experiments conducted on the influence of low temperatures and high salinities on sex ratio of progeny produced by infected females. The adverse effects of these extrinsic factors on the development of the vegetative stages, particularly of O. effeminans, demonstrate that the primary sex-deciding mechanisms can be restored: The young born free of microsporidians may differentiate either into females or males according to their genetic background and the photoperiod to which they are exposed. With reference to the observed responses to extreme abiotic conditions, these findings throw some light on an ecological aspect of this host-parasite relationship: The host is more resistant to elevated external salinities than its parasite O. effeminans and, further, O. effeminans is more sensitive to an increase of the osmoconcentration within the host's organism than is $T$. berediteria.

Apart from the interaction of parasitic and external factors there is some indication of influence by the genotypes of the host as well as of the parasites on sex-ratio expression. This is reflected by differences in the response to microsporidian infestations, as demonstrated by breedings of strains selected from various populations. The occurrence of imperfectly thelygenic traits due to a partial infection of the oocytes and the appearance of males associated with the parasites in certain populations of $G$. $d$. duebeni (island of Bornholm) and $G . d$. celticus strongly suggests the importance of the genotype of the host and/or of the parasites. Whether this assumption is true in all instances, deserves further study by experimental transfers of the microsporidians on and crossbreedings between members of various populations.

Differences in the response of the host to microsporidian infestations became visible with regard to the male sexual phenotype. As reported above, the presence of O. effeminans in males of the Bornholm population does not bring about an alteration of the phenotype. On the contrary, experimental transfers of O. effeminans into males derived from populations of the Elbe estuary (Bulnheim, 1977) and the Fjord of Schlei (unpublished results) provoked changes of the phenotype towards an intersexual appearance. The relative growth of the secondary male characters (antennae, gnathopods, third uropods) was progressively reduced and, in addition, oostegites (broodplates of the female) arose, although there was no transformation of the testes into ovarial 
tissue, which is regarded to be the source of a hormone controlling the development of this external female character (cf. Charniaux-Cotton, 1972).

In contrast to photoperiod, temperature and salinity play an indirect role as regulating factors in sex expression of progeny born from parasitized females. As demonstrated above, low temperature levels may retard the schizogonic multiplications of $O$. effeminans and $T$. berediteria in the ovary. Thus, a varying number of eggs may be released free of microsporidians and, consequently, the emerging young may develop into females or males according to genetic and photoperiodic conditions.

Similarly, salinity exerts an indirect influence. Restricted to individuals infested with $O$. effeminans, salinities between 25 and $30 \%$ and higher levels suppress the divisions of the vegetative stages and thus bring about a shift of sex ratio of progeny.

A direct or indirect influence of temperature on sex determination and sex differentiation has been ascertained in several other crustaceans. Details are given in a review recently published by Ginsburger-Vogel (1975d). In the following, temperature effects as related to sex-ratio alterations will be considered with particular reference to other amphipods.

In Orchestia gammarellus and O. montagui monogeny phenomena have been also observed. Thelygeny linked to intersexuality has been established as occurring in various populations of both species. Evidently, this sex-ratio condition is caused by an infectious feminizing factor, which is also transferred to the offspring through the maternal line (Ginsburger-Vogel, 1973, 1974).

In O. gammarellus the expression of thelygeny depends on temperature to a certain extent. Breedings performed with thelygenic females (from Penzé, France) yielded high rates of female descendants associated with some male intersexes. At $22^{\circ} \mathrm{C}$, however, the same parental animals produced mixed progeny or imperfectly or perfectly arrhenogenic broods. From the sex ratios observed, Ginsburger-Vogel (1974, $1975 \mathrm{~b}, \mathrm{c})$ concluded an inversion of genetically determined males into females whose genetic constitution, as revealed by the sex ratios of their progeny, is masked at $17^{\circ} \mathrm{C}$ but expressed at $22^{\circ} \mathrm{C}$. Apart from the genetic interpretation and its consequences temperature could be shown to exert an indirect effect on the composition of O. gammarellus broods: As revealed by exposure of thelygenic $q O+$ to $25^{\circ} \mathrm{C}$ and subsequent examination of sex ratio of their offspring, the period of the thermal influence is confined to oogenesis and embryonic development.

The occurrence of an epigenetic feminizing factor as responsible for the aberrant sex-ratio condition has been suggested for the following reasons: It can be transferred by grafts of organs of thelygenic $90+$ or male intersexes (a) into amphogenic $ㅇ ㅜ$ which, thereafter, give birth to thelygenic broods and (b) into males which develop into intersexes provided that they are not maintained at temperatures above $17^{\circ} \mathrm{C}$ following implantation. In a preliminary report Ginsburger-Vogel et al. (1976) presented evidence for an infestation of thelygenic O. gammarellus females by a parasitic organism that acts as the feminizing factor suggested. Some of its characters resemble those of haplosporidians. With regard to its cellular organization, which is similar to that of the protist Marteilia refringens, a parasite of oysters, it appears to be a Marteilia species (Desportes \& Ginsburger-Vogel, 1977).

In addition, thelygeny associated with intersexuality was found in certain O. gam- 
marellus strains which, in regard to the sex-ratio aberration recorded, were not sensitive to elevated temperatures. Such thermal resistance could also be observed in thelygenic strains obtained from O. montagui (Ginsburger-Vogel, 1974, 1975b).

Thelygeny brought about by genetic mechanisms different from those outlined in the foregoing occurs in O. gammarellus populations of pebble beaches. In these, males appear to play a decisive role in the inheritance of monogeny (Ginsburger-Vogel, 1975a). Although more information on the monogeny phenomena established in Orchestia is required, parallels to $G$. $d$. duebeni become evident with reference to the parasite suggested as being associated with thelygenic females and, concerning its feminizing influence, the sensitivity to environmental variables.

The complexity of the sex-determining mechanisms analyzed in some of the amphipod species studied appears to be similar to that elucidated in several isopods (cf. Legrand \& Legrand-Hamelin, 1975). Recent findings gained from Armadillidium vulgare also indicate the occurrence of epigenetic feminizing factors which, by reversing the phenotype of genetic males, appear to be causative agents of thelygeny. In certain populations of this isopod, bacteria-like particles could be detected as associated with thelygenic females and transferred via the eggs to their offspring (Martin et al., 1973), whereas in other populations thelygeny does not appear to be caused by these organisms (Juchault \& Legrand, 1976).

Further, an infectious masculinizing epigenetic factor is assumed to exist in Porcellio dilatatus dilatatus and to cause male intersexuality. It is transmitted to some of the descendants through the maternal as well as the paternal line. Although its exact nature is not yet known, evidence has been presented for its sensitivity to elevated temperatures, since its intersexuality-inducing capacity disappears in the descendants of progenitors which were maintained at $27^{\circ} \mathrm{C}$ (Juchault \& Legrand, 1975).

In Drosophila species temperature effects on the expression of a maternally transmitted sex-ratio condition have been documented as well. As demonstrated by females producing essentially female descendants, this sex-ratio condition is correlated with the presence of Treponema-like spirochetes (Poulson \& Sakaguchi, 1961) which cause the death of most or all male progeny at early developmental stages. Another case of sex-ratio aberration was found in D. bifasciata; it is also associated with male mortality but it appears to be caused by a virus-like agent (Leventhal, 1968). Malogolowkin (1959) has shown for spirochete-bearing strains of $D$. willistoni and D. equinoxialis that the production of unisexual offspring can be eliminated by elevated temperatures. However, the response of sex ratio in different Drosophila species as well as in different traits associated with the pathogen varies. Some strains of spirochetes appear insensitive to the thermal conditions in their hosts while others show a narrow range of temperature tolerance (Poulson, 1963; Williamson, 1965; Counce \& Poulson, 1966). Apparently, the genotypes of the host and the spirochete interact with temperature and other factors in the expression of sex ratio.

A condition similar in some respects is present in the infected $G . d$. duebeni strains examined, though there is no selective mortality due to the infestations. A complex interaction of the three components - the host, the parasite, and the environment determines sex-ratio expression and, further, there is substantial evidence that host genotype as well as microsporidian strains are also of importance. 
The causes for the effects on sex differentiation by the parasites are not clear. Obviously, during early organogenesis, the development of the androgenic gland anlagen is inhibited by the microsporidian infestations. This, consequently, leads to female sex differentiation. The question arises: Do the parasites induce specific actions upon the endocrine system of their host? An attempt was made to gain some knowledge about the processes involved by grafting androgenic glands into $G$. $d$. duebeni females (Elbe population) associated with $O$. effeminans or $T$. herediteria (Bulnheim, 1977). Whereas complete sex reversal was achieved in Thelohania-infected females, Octosporea-infected females only revealed a partial masculinization restricted to their secondary sex characters following the implantation. However, such incompletely sex-reversed individuals display male behaviour as reflected by their precopulatory activity when associated with adult $q$ 우. This indicates that the hormonal effects exerted by the androgenic glands are not completely inhibited. Also, species-specific differences regarding the actions of the parasites upon the endocrine system of the host became apparent when experimental transfers of both microsporidians into adult males were accomplished: No change of sex characters occurred following inoculation of $T$. herediteria, whereas transfer of $O$. effeminans induced an intersexual development of the secondary male characters and the appearance of oostegites.

In this connection it is interesting to note that similar responses have been observed in thelygenic Orchestia gammarellus females (Ginsburger-Vogel, 1975c), which were resistent to masculinization after grafting androgenic glands at $17^{\circ} \mathrm{C}$, but were not resistent if the test animals were maintained at $25^{\circ} \mathrm{C}$. With regard to the thermal sensitivity the same holds true for the induction of male intersexuality following transfer of organs from thelygenic 9 우 or intersexes into normal males which also acquire oostegites. At present, the mode of action, of the diverse feminizing factors on the sexual physiology of both amphipods is an open question and, therefore, requires further analysis.

Comparisons made with microsporidian infections found in other gammarids have not provided evidence for an affection of sex ratio. Infestations by Thelobania ryckegbemi (= Thelobania mülleri var. minuta; cf. Sprague, 1977) in Gammarus pulex pulex and Thelobania spp. in G. locusta and G. salinus (Bulnheim, 1971a, 1972, 1975b) could be observed in females as well as in males. Though these microsporidians are also transferred through the eggs to the offspring, a sex-determining influence on their hosts can be excluded. Anders (1957) recorded the occasional occurrence of intersexual individuals in $G$. pulex subterraneus * associated with a microsporidian whose taxonomic position could not be clearly identified. Unfortunately, no further data are available on this host-parasite relationship.

In this context it is worthy of note that attempts at interspecific transfers conducted with O. effeminans were not successful. Experimental inoculation of this microsporidian was performed using G. zaddachi and G. salinus $9+9$ in order to find out, whether or not the feminizing effect could also be expressed in the progeny of these related species. Neither, however, proved to be susceptible to this parasite.

* Karaman \& Pinkster (1977) tend to believe that Gammarus pulex subterraneus Schneider is either subadult $G$. p. pulex or subadult $G$. fossarum. 
Considering the efficacy of the diverse epigenetic factors in feminizing the offspring produced, a relation to the particular mechanisms of sex determination detected thus far in amphipods could not be found. Direct or indirect evidence for digametic inheritance of sex was provided in Anisogammarus annandalei (Niiyama, 1950), Gammarus cherreuxi (Traut, 1962), G. locusta (Bulnheim, 1972), Orchestia cavimana (Ginsburger-Vogel, 1972) and O. gammarellus (Ginsburger-Vogel, 1975a), whereas polygenic sex determination is assumed to occur in G. pulex subterraneus (Anders, 1957), G.d.duebeni (Traut, 1962; Bulnheim, 1969) and G. zaddachi (Bulnheim, 1972). Among these species, the different modes of sex determination evidenced in G.d.duebeni and O. gammarellus can be totally overruled by the action of epigenetic factors which reverse the phenotype of the male progeny and thus mask the action of the sex genes. By contrast, sex determination in G. locusta that appears to be based on sex digamety is not affected by the transovarially transferred microsporidian Thelobania sp.

\section{Thelygeny and sex ratio in natural populations}

Finally, the problem of sex ratios in the field will be briefly considered, although no conclusive statements can be made about the effects of monogeny on sex proportions in natural Gammarus duebeni duebeni populations.

The long-term studies conducted in the Elbe estuary indicated that annual fluctuations of sex ratio occurred regularly (Table 6). The percentage of males, which was lowest in spring, ranged from ca. $30 \%$ to more than $60 \%$. From the pooled data the mean sex ratio was estimated as 1.4 우 $: 1 \hat{0}$. Kinne (1952) also observed variations of sex ratio in a $G$. $d$. duebeni population inhabiting the brackish-water lake "Kleiner Kiel“. The percentage of males in samples taken each month from 1950 to 1951 was between $26 \%$ and $56 \%$. A shift in favour of the males occurred in July, whereas in March their number was lowest. The mean sex ratio in this locality amounted to 2.7 우 : 1 ô. In samples taken from a brackish-water population at Gansey Beach (Isle of Man, U. K.), females also prevailed during February to April but in most months of the observation period the males preponderated (Hynes, 1954). Also, in a population inhabiting Lake Storvatnet (Norway), the males dominated for most of the year (Solem, 1969). In a population studied at Holyrood (Newfoundland), sex ratio was never found to be biased toward the females (Steele \& Steele, 1969); it was approximately equal and shifted in favour of the males during summer.

It is difficult to estimate to which extent sex ratios in the Elbe and Kiel population might be affected by the occurrence of perfectly and imperfectly thelygenic $q$ ㅇ. In the population inhabiting the "Kleiner Kiel" only indirect evidence for the presence of $O$ q $q$ infested with microsporidians is available owing to the thelygenic characteristics of some broods which became evident in Kinne's (1952) and Traut's (1962) breeding experiments. The percentage of thelygenic $q O$ in that population as estimated from samples of females scored by the sex ratios of their offspring appeared to be rather high in 1957; from 27 qO tested 16 yielded all-female broods, whereas in a sample taken in 1960 only 3 of 25 우 were thelygenics (Traut, 1962). Later, in 1969, proof 
could be furnished for the occurrence of infestations by Octosporea effemians in 우오 of the Kiel population (see Table 5).

There is reason to suppose that thelygeny may have a significant effect on the overall sex ratio in natural populations. Considering an equally composed population comprising perfectly thelygenic $\$ O+$, which give birth only to thelygenic daughters, and amphogenic $q+$, that produce mixed offspring, an increase of thelygenics twice as fast as amphogenics is to be expected under conditions of random mating. After some generations such a population should become extinct due to the spreading of the allfemale strain and the progressive decline of the number of males. Shaw (1958), in a study on population genetics of sex ratio, has analyzed a model situation of unisexuality similar to thelygeny of $G, d$. duebeni and demonstrated that the bias in sex ratio will continue to increase until no males are left and the population is extinguished.

The findings on sex-ratio alterations in the population of the Elbe estuary indicated that this does not happen or perhaps not as fast as might be expected. Although sex ratio in the field shows considerably seasonal fluctuations, an underlying trend expressed by a gradual decline of the number of males did not become evident during the observation period. A steady increase of the females associated with the microsporidians could not be noted either. Some sort of equilibrium in sex ratio also appears to occur in other coastal G. $d$. duebeni populations of the Baltic Sea and North Sea area in which infestations by Octosporea effeminans and/or Thelobania herediteria have been demonstrated to be present. A comparison of various components of fitness such as brood size, growth rate, and length of life did not reveal any selective advantages of non-infected individuals. Also, neither frequency-dependent mating preference of the males nor different sequences of emergence in normal and infected broods could be established. It is possible, therefore, that other factors might interfere and contribute to the maintenance of sex ratios that do not become disadvantageous to the population.

From the experimental results obtained, temperature must be considered as a regulating factor of some importance. To various degrees, it may suppress the sex-ratio aberration exhibited in the progeny of parasitized females, when it declines below $4^{\circ} \mathrm{C}$ during winter time. Salinity, however, does not play a significant role for the control of sex ratio in nature. The reasons are the following: First, the adverse effects of elevated salinities are restricted to O. effeminans and second, in the habitats preferred, G. d. duebeni is not regularly exposed to such levels which are harmful to the microsporidian parasite (see Table 2).

The situation in the field is still more complex in view of the occurrence of imperfectly thelygenic females and the influence of photoperiod on sex ratio of progeny derived from non-infected individuals. These circumstances, at least in part, may also contribute to a compensation of biased proportions of the two sexes.

With the information at hand, it is difficult to imagine that thelygeny is not disadvantageous to small-sized populations, in particular for those inhabiting rock pools, lagoons, and other isolated areas as well as to a successful establishment of new colonies by a few founders. The question arises: Does a dead-end phenomenon actually occur in such $G$. $d$. duebeni populations or can they persist despite the thelygenic condition imposed on them by the existence of infected females? At present it is not appropriate 
to speculate on this unsolved problem in more detail, since it cannot be excluded that additional factors in the field might be involved in the control of sex ratio.

Acknowledgements. I wish to thank Drs. M. Diehl (Lübeck, FRG), J. Dieleman (Amsterdam, The Netherlands), B. Ganning (Stockholm, Sweden), K. J. Purasjoki (Helsinki, Finland), D. H. Steele (St. John's, Nfld., Canada), W. Vader (Tromsø, Norway) for assistance in the field or supply with live specimens respectively. Thanks are extended to Professor O. Kinne (Hamburg) for advice given during the early stages of this investigation. I am indebted to Drs. M. Hoppenheit and $H$. von Westernhagen (Hamburg) for critical comments on the manuscript of this paper and to Miss M. Mühlenkamp and Mrs. S. Bahns for valuable technical assistance.

\section{LITERATURE CITED}

Anders, F., 1957. Über die geschlechtsbeeinflussende Wirkung von Farballelen bei Gammarus pulex ssp. subterraneus (Schneider). Z. Vererbungsl. 88, 291-332.

Bacci, G., 1965. Sex determination. Pergamon Press, Oxford, 306 pp.

Becker-Carus, C., 1967. Die Bedeutung der Tageslänge für die Ausbildung des Geschlechts bei Armadillidium vulgare (Isopoda). (Experimentelle Verschiebung des Geschlechtsverhältnisses.) Crustaceana 13, 137-150.

Bulnheim, H.-P., 1965. Untersuchungen über Intersexualität bei Gammarus duebeni (Crustacea, Amphipoda). Helgoländer wiss. Meeresunters. 12, 349-394.

- 1967a. Mikrosporidieninfektion und Geschlechtsbestimmung bei Gammarus duebeni. Zool. Anz. (Suppl.) 30, 432-442.

- 1967b. Über den Einfluß der Photoperiode auf die Geschlechtsrealisation bei Gammarus duebeni. Helgoländer wiss. Meeresunters. 16, 69-83.

- 1969. Zur Analyse geschlechtsbestimmender Faktoren bei Gammarus duebeni (Crustacea, Amphipoda). Zool. Anz. (Suppl.) 32, 244-260.

- 1971a. Entwicklung, Übertragung und Parasit-Wirt-Beziehungen von Thelohania herediteria sp. n. (Protozoa, Microsporidia). Z. Parasitkde 35, 241-262.

- 1971b. Über den Wirtskreis der Mikrosporidie Stempellia mülleri. Arch. Protistenk. 113, $137-145$.

- 1972. On sex-determining factors in some euryhaline Gammarus species. In: 5th European Marine Biology Symposium. Ed. by B. Battaglia. Piccin, Padova, 115-130.

- 1975a. Intersexuality in Gammaridae and its conditions. Pubb1. Staz. zool. Napoli 39 (Suppl.), 399-416.

- 1975b. Microsporidian infections of amphipods with special reference to host-parasite relationships: A review. Mar. Fish. Rev. 37 (5-6), 39-45.

- 1977. Geschlechtsumstimmung bei Gammarus duebeni (Crustacea, Amphipoda) unter dem Einfluß hormonaler und parasitärer Faktoren. Biol. Zbl. 96, 61-78.

- 1978. Variability of the modes of sex determination in littoral amphipods. In: Genetics, ecology and evolution of marine organisms. Plenum Press, London (in press).

- \& Vávra, J., 1968. Infection by the microsporidian Octosporea effeminans sp. n., and its sex determining influence in the amphipod Gammarus duebeni. J. Parasit. 54, 241-248.

Charniaux-Cotton, H., 1972. Recherches récentes sur la différenciation sexuelle et l'activité génitale chez divers Crustacés supérieurs. In: Hormones et différenciation sexuelle chez les Invertébrés. Ed. by E. Wolff. Gordon \& Breach, New York, 3, 127-178.

Counce, S. J. \& Poulson, D. F., 1966. The expression of maternally-transmitted sex ratio condition (SR) in two strains of Drosophila melanogaster. Genetica 37, 364-390.

Dalens, H., 1971. Contribution à l'étude des phénomènes d'intersexualité et de monogénie dans le genre Chaetophiloscia (Isopoda, Oniscoidea). II. La monogénie chez Chaetophiloscia elongata (Dollfuss) et Ch. sicula (Verhoeff). Bull. biol. Fr. Belg. 105, 3-52. 
Desportes, I. \& Ginsburger-Vogel, T., 1977. Affinités du genre Marteilia, parasite d'Huîtres (maladie des Abers) et du Crustacé Orchestia gammarellus (Pallas), avec les Myxosporidies, Actinomyxidies et Paramyxidies. C. r. hebd. Séanc. Acad. Sci., Paris (D) 285, 1111-1114.

Ginsburger-Vogel, T., 1972. Démonstration expérimentale de l'homogamétie femelle chez Orchestia cavimana (Heller) (Crustacés Amphipodes Talitridae). C. r. hebd. Séanc. Acad. Sci., Paris (D) 275, 1811-1813.

- 1973. Détermination génétique du sexe, monogénie et intersexualité chez Orchestia gammarella Pallas (Crustacé Amphipode 'Talitridae). I. Phénomènes de monogénie dans la population de Penzé. Arch. Zool. exp. gén. 114, 397-438.

- 1974. Détermination génétique du sexe, monogénie et intersexualité chez Orchestia gammarella Pallas (Crustacé Amphipode Talitridae). II. Etude des relations entre la monogénie et l'intersexualité. Influence de la température. Arch. Zool. exp. gén. 115, 93-127.

- 1975a. Détermination génétique du sexe, monogénie et intersexualité chez Orchestia gammarella Pallas (Crustacé Amphipode Talitridae). III. Etude de phénomènes de monogénie indépendants de l'intersexualité. Arch. Zool. exp. gén. 116, 615-647.

- 1975b. Les phénomènes de monogénie liés a l'intersexualité et leur thermosensibilité; étude comparée chez Orchestia gammarella Pallas et Orchestia montagui (Audouin) (Crustacés Amphipodes Talitridae). Pubbl. Staz. zool. Napoli 39 (Suppl.), 417-442.

- 1975c. Temperature-sensitive intersexuality and its determinism in Orchestia gammarella Pallas. In: Intersexuality in the animal kingdom. Ed. by R. Reinboth. Springer, Berlin, 106-120.

- 1975d. Température et differenciation sexuelle chez les crustacés. Bull. Soc. zool. Fr. 100, 95-115.

—, Desportes, I. \& Zerbib, C., 1976. Présence chez l'Amphipode Orchestia gammarellus (Pallas) d'un Protiste parasite; ses affinités avec Marteilia refringens agent de l'épizootie de l'Huître plate. C. r. hebd. Séanc. Acad. Sci., Paris (D) 283, 939-942.

Hynes, H. B. N., 1954. The ecology of Gammarus duebeni Lilljeborg and its occurrence in freshwater in western Britain. J. Anim. Ecol. 23, 38-84.

Juchault, P. \& Legrand, J.-J., 1975. Modalités de la transmission héréditaire du facteur épigénétique responsable de l'intersexualité masculinisante chez le Crustacé Oniscoide Porcellio dilatatus Brandt. Bull. Soc. zool. Fr. 100, 467-476.

- - 1976. Modification de la sex-ratio dans les croisements entre différentes populations du Crustacé Oniscoide Armadillidium vulgare Latr. Notion de déterminisme polygénique et épigénétique du sexe. Arch. Zool. exp. gén. 117, 81-93.

Karaman, G. S. \& Pinkster, S., 1977. Freshwater Gammarus species from Europe, North Africa and adjacent regions of Asia (Crustacea-Amphipoda). I. Gammarus pulex-group and related species. Bijdr. Dierk. 47, 1-97.

Kinne, O., 1952. Zur Biologie und Physiologie von Gammarus duebeni Lillj. III. Zahlenverhältnis der Geschlechter und Geschlechtsbestimmung. Kieler Meeresforsch. 9, 126-133.

- 1953. Zur Biologie und Physiologie von Gammarus duebeni Lillj. VII. Über die Temperaturabhängigkeit der Geschlechtsbestimmung. Biol. Zbl. 72, 260-270.

- 1959. Ecological data on the amphipod Gammarus duebeni. A monograph. Veröff. Inst. Meeresforsch. Bremerh. 6, 177-202.

- 1961. Die Geschlechtsbestimmung des Flohkrebses Gammarus duebeni Lillj. (Amphipoda) ist temperaturabhängig - eine Entgegnung. Crustaceana 3, 56-69.

Kosswig, C., 1964. Polygenic sex determination. Experientia 20, 190-199.

Legrand, J.-J. \& Legrand-Hamelin, E., 1975. Déterminisme de l'intersexualité et de la monogénie chez les Crustacés Isopodes. Pubbl. Staz. zool. Napoli 39 (Suppl.), 443-461.

Legrand-Hamelin, E. \& Mocquard, J. P., 1976. Influence de la température et de la photopériode sur l'inversion du sexe et sur l'intersexualité d'Idotea baltbica Pallas (Isopode Valvifère). Bull. Soc. zool. Fr. 101 (Suppl. 4), 54-75.

Le Roux, M.-L., 1933. Recherches sur la sexualité des Gammariens. Bull. biol. Fr. Belg. (Suppl.) 16, 1-138. 
Leventhal, E., 1968. The sex ratio condition in Drosopbila bifasciata; its experimental transmission to several species of Drosophila. J. Invert. Pathol. 11, 170-183.

Malagolowkin, C., 1959. Temperature effects on maternally inherited "sex-ratio" conditions in Drosopbila willistoni and Drosopbila equinoxialis. Am. Nat. 93, 365-368.

Martin, G., Juchault, P. \& Legrand, J.-J., 1973. Mise en évidence d'un micro-organisme intracytoplasmique symbiote de l'Oniscoide Armadillidium vulgare. Latr. dont la présence accompagne l'intersexualité ou la féminisation totale des mâles génétiques de la lignée thélygène. C. r. hebd. Séanc. Acad. Sci., Paris (D) 276, 2313-2316.

Niiyama, H., 1950. The X-Y mechanism of sex chromosome in the male of Anisogammarus annandalei (Tattersall) (Crustacea: Amphipoda). Annot. zool. jap. 23, 58-62.

Poulson, D. F., 1963. Cytoplasmic inheritance and hereditary infections in Drosopbila. In: Methodology in basic genetics. Ed. by W. J. Burdette. Holden-Day Inc., San Francisco, 404-424.

- \& Sakaguchi, B., 1961. Nature of the "sex-ratio" agent in Drosopbila. Science, N. Y. 133, $1489-1490$.

Shaw, R. F., 1958. The theoretical genetics of the sex ratio. Genetics 43, 149-163.

Solem, J. O., 1969. Ecology of Gammarus duebeni Lilljeborg in a Norwegian lake. K. norske Vidensk. Selsk. Skr. 2, 1-12.

Sprague, V., 1977. Annotated list of species of Microsporidia. In: Comparative pathobiology. Ed. by L. A. Bulla, Jr. \& T. C. Cheng. Plenum Press, New York, 2, 31-334.

Steele, D. H. \& Steele, V. J., 1969. The biology of Gammarus (Crustacea, Amphipoda) in the northwestern Atlantic. I. Gammarus duebeni Lillj. Can. J. Zool. 47, 235-244.

Stock, J. H. \& Pinkster, S., 1970. Irish and French fresh water population of Gammarus duebeni subspecifically different from brackish water populations. Nature (Lond.) 228, 874-875.

Stross, R. G., 1969. Photoperiod control of diapause in Daphnia. II. Induction of winter diapause in the arctic. Biol. Bull. mar. biol. Lab., Woods Hole 136, 264-273.

- \& Hill, J. C., 1968. Photoperiod control of winter diapause in the fresh-water crustacean, Daphnia. Biol. Bull. mar. biol. Lab., Woods Hole 134, 176-198.

Traut, W., 1960. Ist die Geschlechtsbestimmung des Flohkrebses Gammarus duebeni Lillj. (Crust. Amphipoda) temperaturabhängig? Naturwissenschaften 47, 454-455.

- 1962. Zur Geschlechtsbestimmung bei Gammarus duebeni Lillj. und verwandten Arten (Crustacea, Amphipoda). Z. wiss. Zool. 167, 1-72.

Weiser, J., 1976. Microsporidia in invertebrates: Host-parasite relations at the organismal level. In: Comparative pathobiology. Ed. by L. A. Bulla, Jr. \& T. C. Cheng. Plenum Press, New York, 1, 163-201.

Williamson, D. L., 1965. Kinetic studies of "sex ratio" spirochetes in Drosopbila melanogaster Meigen females. J. Invert. Pathol. 7, 493-501. 